
link between tenure security and sustainable land management in cocoa landscapes in Ghana.

(C) 2020 Elsevier Ltd.

This manuscript version is made available under the CC BY-NC-ND 4.0 license https://creativecommons.org/licenses/by-nc-nd/4.0/ (cc) EY-NC-ND

This version is available at https://nora.nerc.ac.uk/id/eprint/527027/

Copyright and other rights for material on this site are retained by the rights owners. Users should read the terms and conditions of use of this material at https://nora.nerc.ac.uk/policies.html\#access

This is an unedited manuscript accepted for publication, incorporating any revisions agreed during the peer review process. There may be differences between this and the publisher's version. You are advised to consult the publisher's version if you wish to cite from this article.

The definitive version was published in World Development (2020), 130. 104913. https://doi.org/10.1016/i.worlddev.2020.104913

The definitive version is available at https://www.elsevier.com/ 


\title{
Questioning the Link between Tenure Security and Sustainable Land Management in Cocoa Landscapes in Ghana
}

\author{
Festus A. Asaaga a,b,*, Mark A. Hirons ${ }^{\mathrm{a}}$ and Yadvinder Malhi ${ }^{\mathrm{a}}$ \\ a Environmental Change Institute, School of Geography and the Environment, University of \\ Oxford, Oxford OX1 3QY, Oxfordshire, UK. Email: fesasa@ ceh.ac.uk/ fasaaga@gmail.com \\ Email: mark.hirons@ouce.ox.ac.uk Email: yadvinder.malhi@ouce.ox.ac.uk \\ ${ }^{\mathrm{b}}$ UK Centre for Ecology and Hydrology, Maclean Building, Benson Lane, Crowmarsh Gifford, \\ Wallingford OX10 8BB, Oxfordshire, UK
}

\begin{abstract}
Sustainable land management (SLM) is increasingly recognized as viable pathway to accelerate poverty reduction and achieving sustainable development, particularly in the global South. Despite efforts to promote SLM practices, their adoption has been extremely limited with debates revolving around the role of land tenure in farmer's decision-making. Drawing on a tripartite conception of tenure security, we distinguish between three categories of tenure security: 1) legal security; 2) contextual/ defacto security, and 3) perceived tenure security to examine factors affecting smallholders' investment in SLM in Ghana. The paper draws on 380 surveys covering 796 plots and a series of key informant interview to investigate how land tenure shapes farmers' investment decisions regarding SLM adoption at the plot level. The findings of the study demonstrate that different types of SLM investments (including soil improvements, on-farm tree planting and conservation of naturally-occurring tree species) were undertaken by farmers, even those who perceived their tenure rights as insecure. However, the results demonstrate that different components of tenure security influence adoption of SLM practices in ways which are not consistent across the different components of tenure security or specific SLM practices. Furthermore, the relationship between tenure security and SLM investments is also mediated by other important non-
\end{abstract}


tenurial factors (including access to credit, modernised agricultural inputs and targeted extension service support). The findings suggest that land tenure policies will deliver a range of outcomes (both positive and negative) pertaining to land conservation investments. This means thinking more deeply about priorities with respect to SLM interventions, particularly in emerging contexts like Ghana and SSA generally. Overall, these findings are important for redesigning context- specific and appropriate land-use policy interventions that address barriers to SLM adoption.

Keywords - Sustainable land management (SLM), Customary land tenure, Tenure security, Adoption, Ghana, Sub-Saharan Africa (SSA) 


\section{Introduction}

Sustainable land management ${ }^{1}$ (SLM) has gained momentum across sub-Saharan Africa (SSA) as a viable pathway towards sustainable development and poverty reduction (Nigussie et al. 2017; Nkonya et al. 2016; Kabubo-Mariara and Linderhof, 2015; UN, 2015; World Bank, 2010). Successive SSA governments (with support from the World Bank and other international development agencies) have promoted SLM as a basis for several land management projects, including the United Nation's Reducing Emissions from Deforestation and Forest Degradation (REDD) initiative (Hirons et al. 2018; Nkonya et al. 2016). In Ghana, for instance, the adoption of SLM practices (notably on-farm tree planting, preservation of naturally-occurring forest trees and soil fertilisation) is widely seen as critical to control widespread deforestation, rehabilitation of degraded farmlands and ensuring optimal use of land, particularly for the majority of smallholder farmers grappling with declining soil fertility, yields and the looming threat of anthropogenic climate change (Antwi-Adjei et al. 2015; GoG, 2014; Kolavalli and Vigneri, 2011). Although evidence on the actual extent of deforestation in Ghana is patchy, it is estimated that the country's forest cover has dwindled from $32.7 \%$ of the total land surface in 1990 to $21.7 \%$ in 2010 with the highest percentage decline of about 26\% loss occurring between 2005 and 2009 alone (Nketiah et al. 2009; GoG, 2014:90). According to the Government of Ghana (2014:90), the cost of environmental degradation is estimated at $\sim 10 \%$ of GDP lost annually through unsustainable management of land and other natural resources. Accordingly, the government of Ghana has recently introduced a suite of policy reforms and initiatives within the land and forestry sector (such as the National Forest Plantation Development Programme (NFPDP) and Ghana Cocoa \& Forest Initiative National Implementation Plan 2018-2020) geared towards boosting productivity and

\footnotetext{
1 This study defines Sustainable land management as involving all those land management practices that are aimed at managing land and other natural resources to produce economic, social and ecological benefits to support livelihoods of the present and future generations (Liniger et al. 2011).
} 
minimising the environmental footprint of the cocoa sub-sector (Hirons et al. 2018; Hajjar et al. 2014; Asare et al. 2010; Nketiah et al. 2009).

Despite SLM being widely recognised (e.g. Nyanga et al. 2016; Nkonya et al. 2016; Kirui, 2016; Kabubo-Mariara, 2006) as a key strategy for effectively addressing environmental degradation challenges, the concept is deeply contested with relatively little consensus in the development debate on how to achieve broadly accepted normative goals concerning livelihood and food security while mitigating climate change and biodiversity and soil losses (FAO, 2011; Nyanga et al. 2016; Blackman et al. 2017; Cordingley et al. 2015; Mbow et al. 2014). This is reflected in the extremely limited uptake of SLM practices such as on-farm tree planting and conservation of naturallyoccurring trees by smallholder farmers across the continent (Nkonya et al. 2016; Cordingley et al. 2015; Mbow et al. 2014; Insaidoo et al. 2013; World Bank, 2010).

Previous theoretical and empirical research suggest that tenure insecurity is one of the key factors which inhibits adoption SLM practices and contributes to increasing environmental degradation across SSA, including Ghana (Nkonya et al. 2016; Damnyag et al. 2012; Abdulai et al. 2011; Twerefou et al. 2011; Kabubo-Mariara, 2007; Boni, 2006; Owubah et al. 2001). It has long been established that ill-defined and insecure property rights can, in principle, discourage farmers from undertaking land-improving investments given the uncertainty and risk of future expropriation by land owners (Fenske, 2011; Unruh, 2008; Besley, 1995; Feder et al. 1988). Furthermore, research on the security-investment relationship have shown that issuance of formal legal titles can incentivize farm investments (Place, 2009) by strengthening land claims and enhancing farmers' credit access (Feder et al. 1988; de Soto, 2000; Feder and Nishio, 1999). However, titling can also operate to encourage extensification and other unsustainable land-use practices by fuelling contestations over land especially in legally pluralistic contexts (Berry, 2009; Abdulai and OwusuAnsah, 2014; Peters, 2009; Meinzen-Dick and Mwangi, 2009), and reinventing common-pool 
resource problems on local level, which communities may or not be willing to tackle (Ostrom, 2010; Blackman et al. 2017).

Empirical evidence on the interactions between tenurial arrangements, agricultural investments and SLM in SSA is patchy and altogether inconclusive, with wide variations in results across different regions (Persha et al. 2015; Ayamga and Dzanku, 2013; Fenske, 2011; Arnott et al. 2011, Place, 2009). Studies examining SLM adoption in SSA have tended to focus on the biophysical aspects and benefits to the relative neglect of the underlying socio-economic, political and/ or institutional factors that that operate to constrain widespread adoption (Nkonya et al. 2016; Persha et al. 2015; Mbow et al. 2014). Furthermore, those studies (e.g. Twerefou et al. 2011; Damnyag et al. 2012; Abdulai et al. 2011; Ayamga et al. 2015; Nyanga et al. 2016) that have examined the securityinvestment nexus have overlooked the interplay of other important security-related factors (beyond the legal dimension) in shaping tenurial outcomes. Consequently, how contextual factors such as length of occupation, plot tenure, household socio-political status etc., contribute to or dampen tenure security and how they differentially shape land-use investment decisions of farmers remains unclear.

This paper attempts to fill this gap in the literature by empirically examining the linkages between land tenure arrangements (tenure security) and SLM adoption, drawing on fieldwork undertaken in Ghana. The paper draws on a tripartite conceptualization of tenure security (as legal, defacto and perceived $)^{2}$, to examine how these different elements of tenure security interact in shaping land use decisions of farmers regarding adoption of SLM practices. By moving beyond the conventional legal conceptualisation of tenure towards a multi-dimensional understanding, the analys is

\footnotetext{
2 Tenure security in this study is conceptualised as a multi-dimensional concept. The legal/ dejure dimension pertains to a landholder's possession of a formal documentation as evidence of ownership or use, which is duly recognised by the appropriate land management institutions. Perceived tenure security relates to the individual or household's experience of their tenure situation, which is the probability of losing all or some of their rights in land. Defacto security in this study refers to the actual condition that affects landholders' ownership or use of a property regardless of the legal status in which it is held.
} 
illuminates the interplay of these different components of tenure security in shaping land use decisions, and in doing so develops a framework for developing context-specific and appropriate SLM strategies that are required in light of the general failure of one-size-fits-all top-down exogenous approaches (Lawry et al. 2017; Ayamga et al. 2016; Bromley, 2009). The specific findings of the paper are relevant for on-going developments in Ghana's cocoa sector, which is grappling with how to operationalise sustainable intensification and 'climate-smart' strategies (Fuentes et al. 2012; Asare, 2013; Insaidoo et al. 2013).

The rest of this paper is organised as follows. The next section presents the theoretical framework for the study followed by the research methodology in Section 3. The fourth section presents the empirical results and discussion. The final aspect reflects on the key findings and concludes with some policy implications.

\section{Conceptualising Tenure Security and Farm-Level Investments}

The core argument this paper assesses is that uncertainty in land ownership reduces farmers' investment propensity in long-term SLM practices and that increasing individualization of land rights improves the tenure security and certainty of farmers' recouping their investments made on land (Feder, 1990; Pagiola, 1999; IFPRI, 2012). While this argument is theoretically compelling, it should not be assumed that the lack of formal individualized titles to land automatically equates to tenure insecurity (Bugri, 2008; Lawry et al. 2017). Furthermore, considering the mixed and inconclusive empirical evidence on the titling and investment nexus (see Table 1), some writers (e.g. Platteau, 1996; Bugri, 2008; Bromley, 2009; Sjaastad and Cousins, 2009; Ayamga and Dzanku, 2013) have thus concluded that simplistic prescriptions of land titling as a pathway to enhancing investment incentives can be misleading. In fact, Berry's (2009) cross-country study of Ghana, Côte d'Ivoire and Benin concluded that the privatization of land rights may rather operate in the opposite direction- entrenching inequalities within communities and fuelling contestations 
over land based on origin and social belonging. Other studies have corroborated Berry's (ibid) assertion highlighting instances of social exclusion and inequalities in land distribution amongst the poor and vulnerable groups occasioned by the introduction of formal land titling approaches (see Peters, 2009; Meinzen-Dick and Mwangi, 2009). It therefore follows that there is more to tenure security than just formal titles and more factors influencing investments than land tenure security (Bugri, 2008; Goldstein and Udry, 2008; Lawry et al. 2017).

In investigating the links between tenure and agricultural investment, it is therefore necessary to adopt a sophisticated and multi-dimensional conceptualisation of tenure. Within this purview, despite the widespread consensus on the importance of tenure security, defining its constitution and operationalisation remains a major analytical quandary, particularly in the SSA context where the concept has generated lots of controversy (Obeng-Odoom and Stilwell, 2013; Simbizi et al. 2014; Lawry et al. 2017; Asaaga and Hirons, forthcoming). Whilst varied perspectives have emerged in the land tenure literature about the constitution of tenure security and its sources (Broegaard, 2013; Arnot et al. 2011; Van Gelder, 2010; Sjaastad and Bromley, 2000), conventional analysis on the security-investment relationship have tended to focus solely on the legal dimension overlooking 
Table 1: The Mixed Empirical Evidence of Tenure-SLM Linkages

\begin{tabular}{|c|c|c|c|}
\hline Paper/Author & Countries & Key Finding & $\begin{array}{l}\text { Conceptualisation } \\
\text { of Tenure Security }\end{array}$ \\
\hline [1] Abdulai et al. (2011) & Ghana & Concluded that full individualised land ownership rights significantly influence investments in soil & Legal \\
\hline [9] Ayamga et al. (2016) & Ghana & $\begin{array}{l}\text { Individual land ownership increased both the probability of investing and level of investments } \\
\text { made in land improvement and irrigation in three distinct ecological zones of Ghana - the Northern } \\
\text { Agriculture Zone, the Afram Basin, and the Southern Horticulture Belt. . }\end{array}$ & Legal \& Defacto \\
\hline [11] Besley (1995) & Ghana & $\begin{array}{l}\text { Improved tenure security enhanced agricultural investment in the Wassa area, but no evidence of } \\
\text { a relationship between tenure security and investment in Anloga. }\end{array}$ & Legal \& Defacto \\
\hline [6] Brasselle et al. (2002) & Burkina Faso & $\begin{array}{l}\text { Concluded that the traditional village order, where it exists, provides the land rights required to } \\
\text { stimulate small-scale investment. }\end{array}$ & Perceived \\
\hline [34] Goldstein \& Udry (2008) & Ghana & $\begin{array}{l}\text { Individuals who had powerful positions in the local socio-political hierarchy have more secure } \\
\text { tenure rights and therefore tended to invest more in land conservation practices in southeast Ghana }\end{array}$ & Perceived \\
\hline [40] Jacoby \& Minten (2007) & Madagascar & $\begin{array}{l}\text { Possession of title had no significant effect on plot specific investment and little effect on land } \\
\text { productivity. }\end{array}$ & Legal \\
\hline [42] Kabubo-Mariara (2007) & Kenya & $\begin{array}{l}\text { Property right regimes affect both the decision to conserve land and the type of conservation } \\
\text { practices used by farmers. }\end{array}$ & Defacto \& Perceived \\
\hline $\begin{array}{l}\text { [43] Kabubo-Mariara \& } \\
\text { Linderhof (2015) }\end{array}$ & Kenya & $\begin{array}{l}\text { The likelihood of adoption of adoption of land management practices is higher where land rights } \\
\text { are more secure and not under common property resources. }\end{array}$ & Defacto \& Legal \\
\hline [53] Nigussie et al. (2017) & Ethiopia & $\begin{array}{l}\text { Plot tenure was found to facilitate investment in traditional stone bunds, application of manure, } \\
\text { and greater total number of SLM measures implemented in the north-western highlands of the } \\
\text { Upper Blue Nile Basin, Ethiopia. }\end{array}$ & Defacto \\
\hline [56] Nyanga et al. (2016) & Tanzania & $\begin{array}{l}\text { There was no significant influence of tenure security on SLM investments. There was only a } \\
\text { tendency that farmers that are have secure tenure rights invested less in their upland fields in the } \\
\text { West Usambara Highlands, Tanzania. }\end{array}$ & Defacto \\
\hline [64] Persha et al. (2015) & Zambia & $\begin{array}{l}\text { Tenure security does appear to have a small positive effect on costly and longer return time land } \\
\text { investments, but not on shorter return investments. }\end{array}$ & Legal \& Perceived \\
\hline $\begin{array}{l}\text { [67] Place \& Migot-Adholla } \\
\text { (1998) }\end{array}$ & Kenya & $\begin{array}{l}\text { Registration and titling program had a weak impact on perceived land rights of farmers, credit use } \\
\text { and terms, crop yields, or concentration of landholdings. }\end{array}$ & Legal \& Perceived \\
\hline
\end{tabular}

Source: Authors compilation from selected illustrative studies 
other important factors that contribute to overall tenure security (Van Gelder and Luciano, 2015; Simbizi et al. 2014; Broegaard, 2013; Ma et al. 2015). However, the burgeoning literature suggests that beyond the issuance of formal land titles, other contextual factors such as social, political and economic resources, local norms and customs and duration of possession operate to influence the overall tenure status of landholders and their ultimate land investment decisions (Ma et al. 2015; Broegaard, 2013; Van Gelder, 2010; Bromley 2009; Toulmin, 2009; Brasselle et al. 2002). Therefore, in operationalising tenure security in this study, we draw on the tripartite notion of tenure security as (i) legal, (ii) defacto, and (iii) perceived following Van Gelder (2010) (see Fig.1).

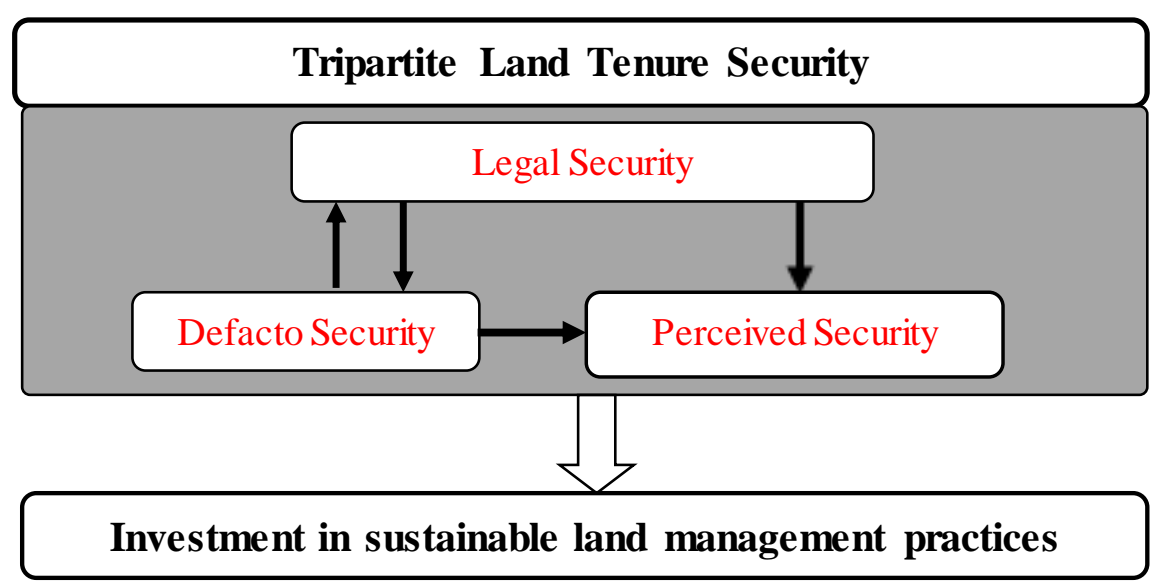

Figure 1: Multi-dimensional Tenure Security and Investment Nexus

The importance of the tripartite framework (Fig. 1) is underscored by the fact that land rights in rural contexts like the case study areas are predominantly undocumented or unregistered, implying that land tenure security is largely attained through sources other than legal. The tripartite conceptualisation thus provides the opportunity to comprehensively assess the actual state of land tenure security and the different factors (legal and extra-legal) influencing security in the study contexts (Van Gelder, 2010; Broegaard, 2013; Ma et al. 2015). To the best of our knowledge, this is the first study in a SSA context that examines the interaction between multi-dimensional tenure and household SLM investment decision-making (see Ma et al. 2015 as a non-SAA exception). Furthermore, other commentators (Bugri, 2008; Robinson et al. 2014) have argued that tenure 
security is a necessary but not sufficient condition for investment in agricultural production and environmental conservation. It is therefore important to incorporate an understanding of how other non-tenurial factors such as financial, labour and input constraints shape or influence landholders' investment decision-making. Improved tenure security (through land titling) may not or may not engender the appropriate incentives for increased investments (cf. ibid; Lawry et al. 2017). Besides, it is even possible that plots registered by farmers already benefit from comparatively high levels of investments, in which case formalized private tenure does not stimulate investment but is only positively associated with it (cf. Bugri, 2008). In any event, some scholars (e.g. Besley, 1995; Sjaastad and Bromley, 1997; Brasselle et al. 2002; Berry, 2009) have observed a reverse causality between investment and tenure security as insecure landholders may undertake certain long-term investments on land, which invariably enhances their defacto tenure security. Sjaastad and Bromley (1997) for instance, argue that though tenure insecurity is a disincentive to invest, it can also be an incentive to invest to increase security. It therefore follows that empirical investigations need to shed light on causal relationships between land titling and security on one hand, and security and investment on the other, especially in customary dominant rural contexts. Against this backdrop, this study investigated land tenure differences in shaping farmers' investment decisions regarding adoption of SLM practices.

\subsection{Overview of Ghana's Land tenure systems}

To provide a contextual background for situating the subsequent empirical analysis, this section presents a brief overview of Ghana's complex land tenure arrangements. Synonymous to other SSA countries, land tenure in Ghana is underpinned by an amalgam of statutory and customary laws that define access and control to land (Agbosu et al. 2007). Approximately $80 \%$ of Ghana's land surface is managed under customary regimes by stools ${ }^{3}$, skins and family heads, with the remaining $20 \%$

\footnotetext{
${ }^{3}$ Stool or skin is the traditional representation of chiefly a uthority in southern and northern Ghana respectively.
} 
under state control (Kasanga and Kotey, 2001; Asaaga and Hirons, 2019; Agbosu et al. 2007). The pluralistic legal framework for land management (exemplified by a seeming disconnect between customary and statutory tenure systems) has been a subject of intense debate, which some scholars (e.g. Kasanga and Kotey 2001: 8) have described as "poorly articulated and being on a collision course'. Despite the numerous attempts to reform the customary land tenure system, land ownership and management remains highly contested characterised by protracted land disputes, insecurity and exclusion, especially among the vulnerable social groups (Asaaga and Hirons, 2019; Hausermann et al. 2018; Lambrecht, 2016; Aryeetey et al. 2007; Berry, 2009; Boone and Duku, 2012). Indeed, the suite of legislations and interventions introduced by colonial and post-independence governments ${ }^{4}$ to restructure the supposedly inefficient customary tenure arrangements rather resulted in two economic systems - a capitalist system in commercial areas and the traditional communal system supporting subsistence agriculture. Within this purview, the capitalist sector instigated the development of individualised private property rights (in favour of European and wealthy local entrepreneurs) which hitherto did not exist (Amanor, 2010; Djokoto and Opoku, 2010). The resultant effect was growing insecurity and social differentiation as land-use patterns in many parts of the country transformed from shifting cultivation to permanent land acquisitions in response to increased demand for oil palm and other forest products occasioned by the industrial revolution (Gyasi, 1994; Amanor, 2001; Yaro et al. 2018).

\footnotetext{
${ }^{4} \mathrm{~A}$ flurry of legislations that vested large parcels of land hitherto under the juris diction of customary authorities was passed under the Nkrumah regime with the underlying political objective of neutralising the potential threat posed by chi eftaincy (see Aryeetey et al. 2007; Djokoto and Opoku, 2010; Arko-Adjei, 2011). Prominently, the Administration of Lands Act, 1962 (Act123) and the State Lands Act, 1962 (Act 125) were enacted to facilitate land acquisition by the state. The operational effect of these legislative instruments, which are still in operation, is that ownership of land does not amount to ownership of the naturally occurring resources of the land, with the former is vested in the state (Yaro et al. 2018). Although the Section 4(3) of the Timber Resources Management Act 1997 (as amended by the Timber Resources Management (Amendment) Act 2002 reviewed the statutory position allowing for land users to have legal right to planted trees in a bid to stimulate afforestation, there is still widespread confusion regarding the ownership of trees, particularly those that are naturally-occurring.
} 
Of the myriad of internal and external factors that instigated the transformation of customary tenure arrangements and institutions (see Akuffo, 200; Djokoto and Opoku, 2010; Firmin-Sellers, 1995), the rapid growth of the cocoa industry accompanied by the mining boom also played a pivotal role, particularly in southern Ghana. Hill (1963), for instance, argues that the quest for land for cocoa farming vis-à-vis the wanton alienation of stool lands to cocoa farmers led to the creation of individual and family land rights from stool lands in many parts of southern Ghana. This derived largely from cocoa cultivation (relative to other food crops) been regarded as both an investment and means of establishing land ownership (Hausermann et al. 2018; Quisumbing et al. 2001; Sjaastad and Bromley, 1997). Indeed, Berry (2009: 1372) has argued the durable and fixed nature of cocoa tree crops (with an average economic life of 25-30 years) has meant that they accumulate histories of ownership, management and use, which both reflect and influence broader changes in tenure arrangements and practices. Within this context, studies (e.g. Amanor and Diderutuah, 2001; Amanor, 2006; Gyasi, 1994) have overtime reported the emergence of land sales and sharecropping contracts to accommodate the growing commercial land pressures. While these emergent sharecropping arrangements created opportunities for both native and migrants alike to access land, the increased demand also propelled the appreciation of land values and led to protracted interethnic conflicts (Yaro et al. 2018; Amanor, 2001; Firmin-Sellers, 1995). Following the rising land values and monetisation, traditional authorities responsible for land allocation practised 'politics of exclusion' denying resources to the poor and vulnerable segment of the community as part of grand scheme to advance their individual interests and that of colonial administrators (Firmin-Sellers, 1995; Berry, 1997; Pottier, 2005; Joireman, 2006). Consequently, the inequalities in access to land occasioned by the individualisation and alienation of communal lands triggered social tensions between natives and their chiefs resulting in conflicts which have even persisted to date, especially in the formerly non-centralised states (Amanor, 2009; Boone and Duku, 2012). These modifications 
to the customary land tenure system have substantially influenced land relations even to date (Berry, 1993; Peters, 2004; Agbosu et al. 2007; Ninsin, 2015; Asaaga and Hirons, 2019).

To counter the problems of tenure insecurity and land conflicts, subsequent policy reforms notably the National Land Policy (NLP) in 1999 and its operationalisation framework, the Land Adminis tration Project (LAP) have been introduced (GoG, 1999). A central tenet of the LAP is the improving efficiency and equity in land management, with customary tenure institutions as a key operational vehicle for achieving this agenda. Whilst these policy reforms appear to hold promise, there are concerns that the LAP has so far not given sufficient attention to the interest of the poor and vulnerable in Ghana and there is the propensity that its implementation would exclude and further marginalise the afore-mentioned in favour of the rich and powerful local actors (see Asaaga and Hirons, 2019; Amanor, 2010; Yankson et al. 2009).

\section{Methodology and Data Considerations}

\subsection{Study Sites}

The analysis is based on data collated from two study sites - Kakum and Ankasa Conservation Areas situated in the Central and Western regions of Ghana respectively (see Fig. 2). The Kakum and Ankasa Conservation Area form part of the 8.2 million ha stretch of the high forest zone (HFZ) spanning the entire southern third of Ghana ${ }^{5}$. In terms of composition, both the Kakum and Ankasa landscapes are dominated by the permanently protected Kakum National Park and Ankasa National Park and surrounding communities, spanning a total area of $360 \mathrm{~km}^{2}$ and $509 \mathrm{~km}^{2}$ respectively. The

\footnotetext{
${ }^{5}$ Ghana's high forest zone covers about $34 \%$ of Ghana's total land area. The zone provides an interesting setting for analysing the complexity of tenurial dynamics given the growing land pressure and associated conflicts occasioned by the concentration of most land-based economic activities, including cocoa, oil palm, timber, rubber and mining in the zone. Although the complexities of tenure is not restricted to cocoa sub-sector, we focus on cocoa landscapes since they are dominate and central to tenure questions and contemporary environmental and development policies such as REDD+. In this view, we focus on the Central and Western regions of Ghana as they represent two of the six important cocoa growing regions in the country, with the Western region alone accounting for over $50 \%$ of Ghana's total cocoa production (Ghana Cocoa Board, 2012). Available statistics suggest that over 800,000 farmers and millions along the value chain depend on cocoa for their livelihood (GSS, 2014).
} 
research was conducted in 19 fringe communities randomly selected in the Kakum and Ankasa landscapes between December 2013 and September 2015. Aside from having similar tenurial and social contexts affording comparability, both study sites were selected because of their representativeness in illustrating and exploring the prevailing tenurial situation in Ghana's high forest zone. Although tenurial issues and land use dynamics have received considerable attention in the HFZ and Ghana generally, the situation in Kakum and Ankasa have had relatively less attention despite their agro-ecological importance and status as designated protected areas. Recent evidence suggests intensifying land pressures particularly for cocoa farming resulting in growing inequalities, conflicts and extensive deforestation in the peripheral areas of the study areas with negative implications for livelihoods and environmental sustainability (Damnyag et al. 2012; IUCN, 2010). Within this purview, most of the land in the off-reserve areas is stool land wholly owned and managed by the traditional authorities, with pockets of privately-owned land also present. Cocoa, oil palm and food crop farming are the dominant economic activities undertaken by households on relatively small plots $(<5 \mathrm{ha})$ in the studied communities, working the land under diverse tenurial arrangements, ranging from customary freehold to customary licenses. The tenurial and ethnic diversity in the studied communities afforded the unique opportunity to explore how differences in socio-cultural dynamics (re-) shape tenurial outcomes and conditions of land rights in the study sites.

\subsection{Sampling and Data Collection}

Using a mixed methods approach data for the study were collated through survey questionnaire administered to a total of 380 farming households randomly selected from 19 villages in Kakum ( $\mathrm{n}=232)$ and Ankasa $(\mathrm{n}=148)$ respectively to solicit information on their household sociodemographic characteristics, tenurial and land use dynamics. Due to the patriarchal organisation of both study areas, the sampled farm-household heads who received attention were mostly (84\%) male. Nevertheless, recognising the importance of gender and ethnicity in tenurial and land use 
dynamics (Quisumbing et al. 2001; Whitehead and Tsikata, 2003), gender was treated as an analytical category. In this vein, aside from female heads, female plot managers within male-headed households were also interviewed to capture specific variations, if any, in tenurial and land use investment decision-making.

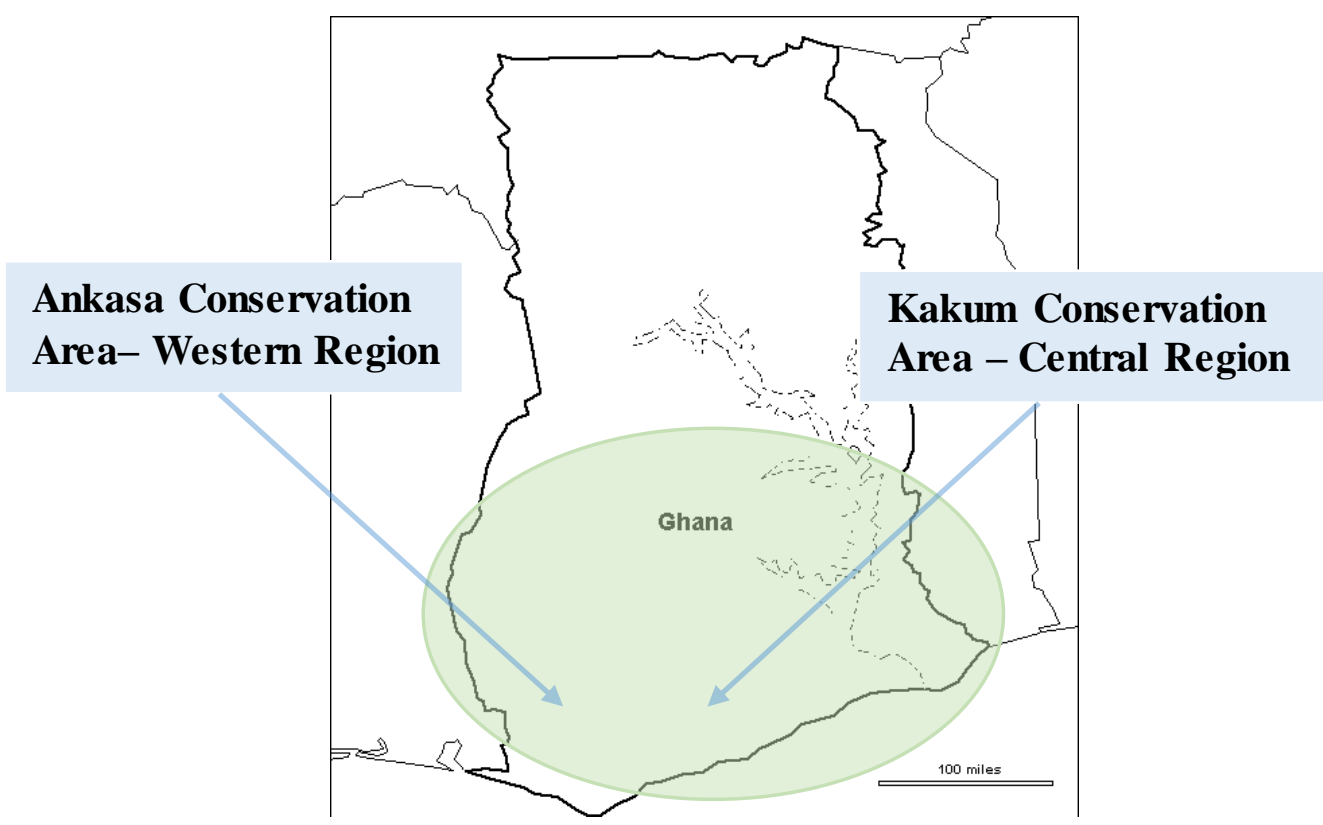

Fig. 2: Overview of the two study sites in Ghana. Green Area illustrates the HFZ. Source: Asaaga and Hirons (2019)

The administered household surveys were supplemented with focus group interviews (in 8 communities) with farmers purposively selected for their in-depth knowledge of the communities, key informant interviews $(n=85)$ with farmers, traditional authorities, district assembly members, farmer cooperative representatives, selected local and national-level officials of key land sector agencies (including from the Assinman Customary Land Secretariat, Office of the Administrator of Stool Lands and Ghana National Land Administration Project Secretariat) and participant observations. This afforded the opportunity to sufficiently explain and capture some local-level nuances on tenurial dynamics which otherwise would have been difficult to capture in a wholly quantitative study. The interview data were transcribed after which a content and thematic analys is 
of the ensuing textual data was undertaken following Miles and Huberman's (1994) three-tier approach to qualitative analysis.

\subsection{Econometric Approach}

Aside from descriptive analysis, a binary logistic regression model was developed (in SPSS) to assess the socio-economic, institutional and biophysical factors that influence farmers' adoption of SLM practices at the plot level. In effect, three sets of logit models were used to analyse the determinants of adoption of three different SLM practices: 1) inorganic fertiliser application, 2) onfarm tree planting, and 3) preservation of naturally-occurring trees. The application of a logistic regression model is predicated on an assumed relationship between the independent and dependent variables evidenced by computing the logit coefficients that compare the probability of a specific SLM practice occurring with the probability of not occurring. The probability of farmers' adoption of an SLM practice in a plot (Y) for one independent variable is given by equation 1 .

$$
\mathrm{P}(\mathrm{Y})=1 / 1+\mathrm{e}-\left(\beta_{0}+\beta_{1} X_{1}+\varepsilon_{i}\right)
$$

Where $\mathrm{P}(\mathrm{Y})$ represents the probability of an SLM practice occurring in a plot. The survey solicited household responses on investments made on inorganic fertiliser application, tree planting and preservation of naturally-occurring forest trees specified as binary variables (i.e. 1 if household has implemented a specific practice and 0 otherwise). $\beta_{0}$ is the $\mathrm{Y}$ intercept or constant term, $\beta_{1}$ is a vector of the regression coefficient, $X_{1}$ is the value of the predictor variable and $\mathrm{e}$ is the base of natural logarithm. However, where there are several predictors as was the case in this study, the probability of adoption of a specific SLM practice is a function of the linear combination of coefficients (-y) as specified in equations 2 and 3:

$$
\mathrm{P}(\mathrm{Y})=1 / 1+\mathrm{e}-\mathrm{y}
$$

Where $Y_{\mathrm{i}}=\beta_{0}+\beta_{1} X_{1}+\beta_{2} X_{2}+\beta_{3} X_{3}+\beta_{4} X_{4}+\beta_{5} X_{5}+\beta_{6} X_{6}+\beta_{7} Z_{i}+\varepsilon_{i}$ 
Where $X_{1}$ to $X_{6}$ are the vectors of the key household and plot-level characteristics, $Z_{i}$ is a vector of study area fixed effects and $\varepsilon_{i}$ is a random error term. Given that both study sites have similar tenurial characteristics vis-à-vis the fact that the same survey instrument was administered during the fieldwork afforded the opportunity of pooling the data and testing for the two study areas effects. Dummy variables are therefore employed in controlling and testing for the specific location effects of Kakum and Ankasa respectively. The specific indicators of the three dimensions of land tenure security (see Fig. 1) were obtained from the literature and respondents' answers to questions about their tenure status. First, legal tenure security is measured by the possession of informal tenure documentation $^{6}$ (such as farm plan and allocation note) evidencing 'legal' ownership or use of land. Second, defacto tenure security is measured by the quality of land rights based on the plot tenure, duration (years) of plot use, incidence of previous dispute and socio-political status. Third, perceived tenure security is measured by three indicators viz. the fear of future expropriation, preferential rights ${ }^{7}$ in land (the right to bequeath land but not sell) and restrictions imposed on land use (see Table 2).

Importantly, the adoption of SLM practices is empirically specified and modelled at the plot-level instead of the household level. This is premised on the assumption that farmers' land management strategies may be different for different plots operated by the same household depending on tenurial and other plot-level factors. The analysis includes data from 796 plots. In effect, the approach

\footnotetext{
${ }^{6}$ The use of informal documents as proxy for legal tenure security derives from the fact that none of the respondents in this study possessed a deeds or title certificate on their plots which are the requisite formal documentation evidencing legal ownership or occupation of land as per the statutory land tenure provisions of Ghana.

7 Drawing on Place and Hazell (1993) categorisation of property rights, we distinguish between complete, preferential and limited rights in land. Complete transfer rights refer to the right of landholders to transfer via outright sale or leaseland to another. This right is akin to customary freehold (often held by individual members of the landholding group, which exist in perpetuity along as the superior allodial title is duly acknowledge). Preferential rights refer to the right of a landholder to bequeath or transfer land to their next of kin inter vivos as inheritance. Under sharecropping and land rental arrangements, landholders (mostly migrant settler farmers) only have limited rights to occupy and use land for a specified duration subject to certain agreed terms with the landowner (see Asaaga and Hirons, 2019).
} 
enabled us to capture specific plot-level variations in investment dynamics pertaining to the aforementioned SLM strategies. The pseudo $R^{2}$, Hosmer-Lemenshow test, maximum likelihood ratio test and -2log likelihood (-2LL) were used in the regression analysis as statistical measures to assess the goodness of fit and eligibility of the predictor variables. The SPSS (version 20) was used to perform the statistical and regression analysis of the data in this paper. Table 2 presents descriptive statistics of the key variables and a priori expectations for the explanatory variables used in the empirical model. 
Table 2: Descriptive statistics of variables used in the regression models and a priori expectations

\begin{tabular}{|c|c|c|c|c|c|}
\hline \multicolumn{2}{|c|}{ Variables } & \multirow{2}{*}{$\begin{array}{l}\text { Definition } \\
\text { A binary indicator of chemical fertiliser application on plot: } 1 \text { if } \\
\text { implemented; } 0 \text { if otherwise }\end{array}$} & \multirow{2}{*}{$\begin{array}{l}\text { Mean } \\
0.750\end{array}$} & \multirow{2}{*}{$\begin{array}{c}\begin{array}{c}\text { Standard } \\
\text { De viation }\end{array} \\
0.433\end{array}$} & \multirow{2}{*}{$\begin{array}{l}\text { Expected } \\
\text { signs }^{8}\end{array}$} \\
\hline SLM practices & Fertiliser application & & & & \\
\hline & On-farm tree planting & $\begin{array}{l}\text { A binary indicator of on-farm tree planting on plot: } 1 \text { if } \\
\text { implemented; } 0 \text { if otherwise }\end{array}$ & 0.350 & 0.477 & \\
\hline & $\begin{array}{l}\text { Preservation of naturally- } \\
\text { occurring trees }\end{array}$ & $\begin{array}{l}\text { A binary indicator of preservation of natural regeneration tree } \\
\text { species on plot: } 1 \text { if implemented; } 0 \text { if otherwise }\end{array}$ & 0.770 & 0.422 & \\
\hline \multicolumn{6}{|l|}{ Explanatory variables } \\
\hline \multirow{10}{*}{$\begin{array}{l}\text { Household } \\
\text { characte ristics }\end{array}$} & Age of Head (years) & Age in years of the household head & 45.210 & 13.024 & $+/-$ \\
\hline & Household Size & Current number of people (members) in household & 7.300 & 3.025 & + \\
\hline & Sex (gender) & $\begin{array}{l}\text { A binary indicator of gender of household head: } 1 \text { if male- } \\
\text { headed; } 0 \text { if female-headed }\end{array}$ & 0.860 & 0.345 & + \\
\hline & No Formal Education & 1 if respondent has no formal education; 0 if otherwise & 0.330 & 0.471 & $+/-$ \\
\hline & Basic Education & 1 if respondent has basic education; 0 if otherwise & 0.670 & 0.471 & + \\
\hline & Secondary Education & 1 if respondent has secondary education; 0 if otherwise & 0.100 & 0.300 & + \\
\hline & Post-Secondary Education & 1 if respondent has post-secondary education; 0 if otherwise & 0.010 & 0.114 & + \\
\hline & Duration of Stay in Village & Residence time in the community in years of the household head & 25.022 & 14.117 & + \\
\hline & Community Membership & $\begin{array}{l}\text { A binary indicator of community membership of household } \\
\text { head: } 1 \text { if migrant; } 0 \text { if indigene }\end{array}$ & 0.870 & 0.341 & $+/-$ \\
\hline & $\begin{array}{l}\text { Household Livestock } \\
\text { Holding }\end{array}$ & $\begin{array}{l}\text { Household total livestock holding in tropical livestock units } \\
\text { (proxy for household wealth) }\end{array}$ & 0.365 & 0.477 & $+/-$ \\
\hline \multicolumn{6}{|l|}{ Tenurial factors } \\
\hline (a) Legal security & Informal Documentation & $\begin{array}{l}1 \text { if respondent has an informal tenure documentation attesting to } \\
\text { use/ownership of land; } 0 \text { if otherwise }\end{array}$ & 0.350 & 0.478 & + \\
\hline \multirow[t]{3}{*}{ (b)Defacto security } & Customary Freehold Land & 1 if respondent operates a customary freehold plot; 0 if otherwise & 0.230 & 0.420 & + \\
\hline & Sharecropped Land & 1 if respondent operates a sharecropped plot; 0 if otherwise & 0.230 & 0.420 & - \\
\hline & Rented Land & 1 if respondent operates a rented plot; 0 if otherwise & 0.180 & 0.382 & - \\
\hline
\end{tabular}

${ }^{8}$ Whereas a plus sign signifies a positive relationship is expected, a minus sign implies a negative relationship based on a priori expectation. Where both plus and minus signs are specified, it implies that no specific a priori expectations are made and the relationship is therefore subject to empirical investigation. 


\begin{tabular}{|c|c|c|c|c|c|}
\hline & Complete Transfer Rights & $\begin{array}{l}1 \text { if respondent has the right to sell or lease out land with or } \\
\text { without approval; } 0 \text { if otherwise }\end{array}$ & 0.410 & 0.493 & + \\
\hline & Preferential Rights & $\begin{array}{l}1 \text { if respondent has the right to bequeath land to children or next } \\
\text { of kin; } 0 \text { if otherwise }\end{array}$ & 0.830 & 0.375 & + \\
\hline & Duration of Plot Use & Number of years' household have used specific plot & 14.665 & 12.314 & + \\
\hline \multirow[t]{3}{*}{$\begin{array}{l}\text { (c) Perceived } \\
\text { security }\end{array}$} & Socio-political Status & $\begin{array}{l}1 \text { if household head or member occupies a position in the } \\
\text { community; } 0 \text { if otherwise }\end{array}$ & 0.490 & 0.500 & + \\
\hline & Previous Land Dispute & $\begin{array}{l}1 \text { if respondent has experienced a previous disputation over } \\
\text { specific household plot; } 0 \text { if otherwise }\end{array}$ & 0.130 & 0.338 & - \\
\hline & Land Use Restrictions & $\begin{array}{l}1 \text { if there are restrictions or conditions on the use of land; } 0 \text { if } \\
\text { otherwise }\end{array}$ & 0.780 & 0.412 & - \\
\hline \multirow[t]{2}{*}{ Plot Characteristics } & Plot Size (in acreage) & Size of household landholding & 4.989 & 5.819 & + \\
\hline & Plot Distance (Kilometres) & Distance from homestead to specific plot & & & - \\
\hline \multirow{4}{*}{$\begin{array}{l}\text { Market } \\
\text { Characteristics }\end{array}$} & Household Credit & 1 if household has access to a credit facility; 0 if otherwise & & & + \\
\hline & Cooperative Membership & $\begin{array}{l}\text { Household head or member affiliated with a farmer cooperative } \\
\text { offering conservation education: } 1 \text { if affiliated; } 0 \text { if otherwise }\end{array}$ & 0.710 & 0.452 & + \\
\hline & Extension Service & $\begin{array}{l}\text { Access to government agricultural extension services: } 1 \text { if } \\
\text { household has access; } 0 \text { if otherwise }\end{array}$ & 0.480 & 0.500 & + \\
\hline & $\begin{array}{l}\text { Willingness to Invest in } \\
\text { agroforestry (if supported) }\end{array}$ & $\begin{array}{l}\text { A five-point Likert scale variable based on the motivation to } \\
\text { invest in tree planting ranging from strongly disagree to strongly } \\
\text { agree. }\end{array}$ & 0.810 & 0.393 & + \\
\hline \multirow[t]{2}{*}{ Location Effects } & Kakum & 1 if household resides at Kakum & 0.680 & 0.466 & $+/-$ \\
\hline & Ankasa & 1 if household resides at Ankasa & 0.320 & 0.466 & $+/-$ \\
\hline
\end{tabular}




\section{Results and Discussion}

\subsection{Adoption of SLM practices}

As evidenced in Table 2 and Figure 3, the overall results suggest that different land management strategies (chemical fertiliser application, on-farm tree planting and preservation of naturallyoccurring tree species) $)^{9}$ were implemented on majority of plots although investment in on-farm tree planting is generally low (35\% or 267 plots) relative to inorganic fertiliser application and preservation of natural regeneration trees. This further highlights the distinct implementation of onfarm tree planting and preservation of natural regeneration trees on plots in the study areas. To explore the influence of the different dimensions of tenure security and other socio-economic factors on households' SLM investment decision-making, further multivariate econometric analysis is undertaken in the ensuing section.

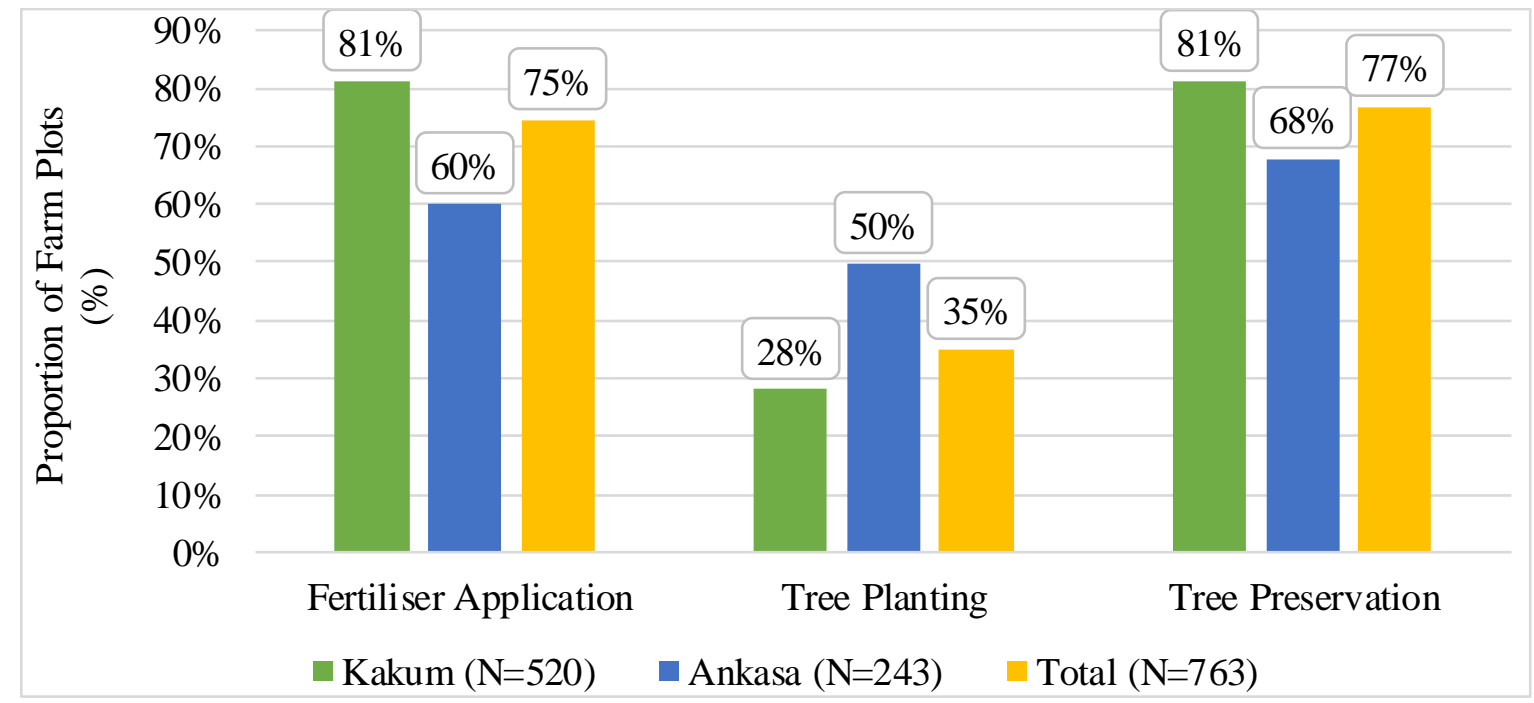

Figure 3: Adoption of different sustainable land management practices

\footnotetext{
${ }^{9}$ It is noteworthy that the unique properties of cocoa (relative to other food crops such as maize and cassava) shape household SLM investment behaviour differently. For instance, the Iongevity and the relatively high market price of cocoa positively affects the quality of land rights to the extent that cocoa farmers may be better-positioned to invest more in say long-term SLM practices (like on-farm tree planting and conservation of naturally-occurring trees) relative to other food crop farmers (see Kolavalli and Vigneri, 2011; Quisumbing et al.2001). Besides, the recent initiatives of free fertiliser distribution to cocoa farmers by the COCOBOD in a bid to boost productivity has also impacted considerably on the uptake of soil fertilisation investment particularly (see Section 4.2.1 and 4.3.2). Therefore, the findings reported here are not generalizable across all crops.
} 


\subsection{Results: Determinants of SLM Adoption}

\subsubsection{Effect of Land Tenure Security on SLM Adoption}

Drawing on the tripartite conceptualisation of tenure security (legal, defacto and perceived), the results in Table 3 demonstrate that different dimensions of tenure have inconsistent effects on SLM investments. Although the three dimensions of tenure security are somewhat interrelated, they are discussed separately for analytical clarity on their differential impacts on SLM adoption.

\section{(a) Legal (dejure) Security and SLM Adoption}

From Table 3, legal security (proxied by informal tenure documentation) exerts opposite effects on fertiliser application (-ve), tree planting (+ve) and tree retention (-ve), but is only statistically significant in the case of the first. The results suggest that farmers tended to invest less in shortterm land improvements on documented plots (deemed as more secure relative to undocumented ones) which is inconsistent with both theory and a priori expectations (see Table 2). This highlights the view that (legal) tenure security can act as both an incentive and disincentive to invest in land. To the extent that the possession of informal documentation increases perceived or defacto security over given plots, landholders could either decide to invest less in soil improvements or defer investments in such plots altogether without any consequences (perceived and actual) to their tenure status. As one sharecropper explained in an interview:

“...Having documentation attesting to the occupation of land guarantees one's stay on the said land and therefore the confidence [certainty] to continuously use land without any fear of losing it. Particularly, for those of us who are sharecroppers (expected to invest in productivity-enhancing practices as condition for the continuous use of land), we may decide to defer the application of fertiliser especially in times of financial difficulty without worrying that the landlord may try to reenter the land once we have some 'legal' [documentation] backing...." (FGD-1, FGD-Bunsu, Kakum). 
This also highlights the practical value of informal tenure documentation as 'significant' proof of ownership/use in the context of the study areas although they lack the force of the law to pass as statutory land documents (Conveyancing Decree, 1974; Asaaga and Hirons, forthcoming). It therefore follows that elaborate land titling may not be necessary in all rural contexts as the standardisation of informal documentation practices can give farmers sufficient legal legitimacy to further bolster the certainty and assurance of protection of rural land rights in Ghana (Asaaga and Hirons, forthcoming). 
Table 3: Econometric model results of factors influencing farmers' adoption of SLM investments in Kakum and Ankasa. In interpreting the results, we use the coefficient and $\operatorname{Exp}(\beta)$ values, where $S E=$ Standard Error; Exp $(\beta)=$ Exponentiation of the $\beta$ coefficient $($ odds ratios for predictors))

\begin{tabular}{|c|c|c|c|c|c|c|c|c|c|}
\hline \multirow[t]{2}{*}{ Variable } & \multicolumn{3}{|c|}{ Inorganic Fertiliser Application } & \multicolumn{3}{|c|}{ On-farm Tree Planting } & \multicolumn{3}{|c|}{ Retention of Naturally-Occurring Trees } \\
\hline & Coefficient & SE & $\operatorname{Exp}(\beta)$ & Coefficient & SE & $\operatorname{Exp}(\beta)$ & Coefficient & SE & $\operatorname{Exp}(\beta)$ \\
\hline \multicolumn{10}{|l|}{ Tenure Security Factors } \\
\hline \multicolumn{10}{|l|}{ Legal security } \\
\hline Informal Documentation & $-0.122 * * *$ & 0.044 & 0.885 & 0.024 & 0.013 & 1.024 & -0.015 & 0.012 & 0.985 \\
\hline \multicolumn{10}{|l|}{ Defacto security } \\
\hline Customary Freehold Land & -0.479 & 0.339 & 0.619 & $-0.754 * *$ & 0.327 & 0.471 & 0.554 & 0.386 & 1.741 \\
\hline Sharecropped Land & -0.201 & 0.270 & 0.818 & $-1.023 * * *$ & 0.251 & 0.359 & -0.035 & 0.267 & 0.965 \\
\hline Rented Land & -0.221 & 0.347 & 0.802 & -0.290 & 0.301 & 0.748 & $0.596 *$ & 0.364 & 1.814 \\
\hline Complete Transfer Rights & 0.027 & 0.245 & 1.027 & -0.180 & 0.225 & 0.836 & -0.025 & 0.248 & 0.975 \\
\hline Preferential Rights & 0.402 & 0.264 & 1.495 & $1.092 * * *$ & 0.291 & 2.981 & 0.105 & 0.274 & 1.111 \\
\hline Duration of Plot Use & $0.045^{* * *}$ & 0.012 & 1.046 & $0.021 * *$ & 0.009 & 1.021 & -0.005 & 0.010 & 0.995 \\
\hline \multicolumn{10}{|l|}{ Perceived security } \\
\hline Socio-political Status & 0.124 & 0.219 & 1.132 & $0.419 * *$ & 0.194 & 1.520 & $0.467 * *$ & 0.219 & 1.595 \\
\hline Previous Land Dispute & 0.106 & 0.298 & 1.111 & $1.075 * * *$ & 0.257 & 2.929 & $0.942 * * *$ & 0.347 & 2.565 \\
\hline Land Use Restrictions & $0.146^{* *}$ & 0.064 & 1.157 & 0.045 & 0.220 & 1.046 & 0.093 & 0.299 & 1.097 \\
\hline \multicolumn{10}{|l|}{ Household Characteristics } \\
\hline Community Membership & -0.240 & 0.321 & 0.787 & 0.414 & 0.301 & 1.513 & $0.678 * *$ & 0.292 & 1.971 \\
\hline Gender of Household Head & -0.034 & 0.321 & 0.967 & 0.446 & 0.309 & 1.562 & -0.069 & 0.306 & 0.933 \\
\hline Age of Household Head & $-0.026 * * *$ & 0.011 & 0.974 & $-0.034 * * *$ & 0.010 & 0.967 & $-0.027 * * *$ & 0.010 & 0.974 \\
\hline Has at least Basic Educ. (relative to none) & -0.342 & 0.238 & 0.710 & 0.016 & 0.216 & 1.016 & -0.010 & 0.233 & 0.990 \\
\hline Has Secondary School Education & $-0.652^{*}$ & 0.351 & 0.521 & -0.220 & 0.336 & 0.802 & $-0.913 * *$ & 0.368 & 0.401 \\
\hline Has Post-Secondary Education & 0.690 & 0.829 & 1.994 & 0.768 & 0.807 & 2.156 & 0.330 & 0.835 & 1.391 \\
\hline Household Size & 0.000 & 0.033 & 1.000 & 0.033 & 0.031 & 1.034 & $0.054 *$ & 0.034 & 1.055 \\
\hline Livestock Holding (in TLU) & 0.231 & 0.240 & 1.259 & 0.048 & 0.194 & 1.049 & 0.034 & 0.240 & 1.034 \\
\hline Duration of Stay in Village & 0.008 & 0.009 & 1.009 & -0.003 & 0.008 & 0.997 & $-0.021 * *$ & 0.009 & 0.979 \\
\hline \multicolumn{10}{|l|}{ Plot Characteristics } \\
\hline Farm Plot Size & $0.055^{*}$ & 0.033 & 1.057 & 0.027 & 0.020 & 1.028 & $0.077 * * *$ & 0.029 & 1.080 \\
\hline Number of Farm Plots & 0.013 & 0.086 & 1.013 & -0.118 & 0.076 & 0.888 & $0.150 *$ & 0.086 & 1.162 \\
\hline Distance to Plot from Homestead & $0.090^{*}$ & 0.047 & 1.094 & 0.003 & 0.037 & 1.003 & 0.034 & 0.048 & 1.035 \\
\hline Market Characteristics & & & & & & & & & \\
\hline
\end{tabular}




\begin{tabular}{|c|c|c|c|c|c|c|c|c|c|}
\hline Access to Credit & 0.077 & 0.429 & 1.080 & -0.680 & 0.370 & 0.506 & $-0.991 * * *$ & 0.394 & 0.371 \\
\hline Access to Gov't Extension Services & 0.322 & 0.206 & 1.380 & $-0.250^{*}$ & 0.192 & 0.779 & 0.020 & 0.206 & 1.020 \\
\hline Cooperative Membership & 0.188 & 0.214 & 1.207 & $0.374 *$ & 0.212 & 1.454 & -0.167 & 0.229 & 0.846 \\
\hline Willingness to Invest (if supported) & - & - & - & $1.054 * * *$ & 0.267 & 2.870 & - & - & - \\
\hline \multicolumn{10}{|l|}{ Location Characteristics } \\
\hline Study Region (1 = Kakum) & $1.632 * * *$ & 0.275 & 5.112 & $-1.104 * * *$ & 0.249 & 0.332 & $0.843^{* * *}$ & 0.271 & 2.324 \\
\hline \multirow[t]{3}{*}{ Constant } & -0.550 & 0.620 & 0.577 & $-1.370 * *$ & 0.669 & 0.254 & 0.063 & 0.658 & 1.065 \\
\hline & \multicolumn{3}{|c|}{$\begin{array}{l}\mathrm{F}-2 \mathrm{LL}=701.093 \\
\text { Cox and Snell R Square }=0.184 \\
\text { Nagelkerke R Square }=0.273\end{array}$} & \multicolumn{3}{|c|}{$\begin{array}{l}\mathrm{F}-2 \mathrm{LL}=813.750 \\
\text { Cox and Snell R Square }=0.204 \\
\text { Nagelkerke R Square }=0.281\end{array}$} & \multicolumn{3}{|c|}{$\begin{array}{l}\mathrm{F}-2 \mathrm{LL}=705.310 \\
\text { Cox and Snell R Square }=0.144 \\
\text { Nagelkerke R Square }=0.218\end{array}$} \\
\hline & \multicolumn{3}{|c|}{$\begin{array}{l}\text { Model Chi-Square }=155.379 * * * \\
\text { Overall percentage } 75.1 \% \text { and } \\
79.6 \% \text { for I and F respectively }\end{array}$} & \multicolumn{3}{|c|}{$\begin{array}{c}\text { Model Chi-Square }=174.192 * * * \\
\text { Overall percentage } 65.0 \% \text { and } \\
71.8 \% \text { for I and F respectively }\end{array}$} & \multicolumn{3}{|c|}{$\begin{array}{l}\text { Model Chi-Square }=118.856 * * * \\
\text { Overall percentage } 76.9 \% \text { and } 78.9 \% \\
\text { for I and F respectively }\end{array}$} \\
\hline
\end{tabular}

I for Initial, $\mathrm{F}$ for Final; * Significant at $\mathrm{p} \leq 0.10 ;{ }^{* *}$ Significant at $\mathrm{p} \leq 0.05 ; * * *$ Significant at $\mathrm{p} \leq 0.01$ 


\section{(b) Defacto Security and SLM Adoption}

The overall results show a mixed relationship between the de facto-security variables and SLM adoption. Interestingly, the customary freehold variable was estimated as insignificant in every model except the on-farm tree planting model (Table 3). Therefore, households appear to invest in fertiliser application and the preservation of naturally-occurring trees regardless of whether their plots are managed on customary freehold basis. This inference is supported by the qualitative analysis as some participants of the community focus groups (FGDs) asserted that the government initiative of free fertiliser distribution to cocoa farmers afforded them the opportunity to undertake such investments primarily to improve land productivity. Indeed, most of the farmers intervie wed highlighted that to the extent that investment in short-term land improvements are directly linked to productivity implied that irrespective of their status of land rights (tenure security), the general predisposition is to undertake such productivity-enhancing measures to realize the associated benefits for themselves and their landlords. A typical explanation in this regard is given by a migra nt sharecropper in Kakum as follows:

"...As a farmer, the fertility of the land is very important as that would influence the productivity of my cultivated crops which is our main source of livelihood. I therefore try to apply chemical fertiliser, manuring and other soil improvement measures if it within my means to ensure that the land remains productive even though the conditions of tenure is not favourable to me..." (FGD-2, Kakum).

Surprisingly, however, the coefficient of the customary freehold variable shows an inverse association with investment in on-farm tree planting suggesting that households with freehold plots are less likely to engage in long-term on-farm tree planting (table 3). This finding is contradictory to both theory and a priori expectation that households' with relatively more secure land rights are more likely to undertake tree planting investments (Besley, 1995; Zhang and Owiredu, 2007; Abdulai et al. 2011). A number of factors could, in combination, explain this finding. Households 
operating customary freehold plots already enjoyed a reasonably high level of defacto security (under customary land tenure) to the extent that the security-enhancing effect occasioned by tree planting investments may be deemed less important. Besides, it may also be that such farmhouseholds are more inclined towards undertaking productivity-based investments with shorter payback periods, in which case, returns from such long-term tree planting investments were quite uncertain given the changing the tenurial contexts in the study areas. During the qualitative interviews, a number of participants asserted that on-farm tree planting was risky given the uncertainty and complexity surrounding the existing benefit-sharing arrangements, attendant destruction to cultivated crops without the payment of any compensation by timber contractors as well as specific land use restrictions imposed by the original landowners. For example, one migrant customary-freeholder in Kakum and an elder of Stool X in Ankasa gave their respective opinions of on-farm tree planting as:

“...On-farm tree planting is not very beneficial, but rather a risky investment. Over here, the onfarm tree logging [activities] has brought untold hardship upon us. All the timber trees we planted [and/ or preserved] on our farms in this area have been granted to timber contractors by the chief. As we speak, fifteen trees have been felled on my farm destroying my cocoa crops in the process without any compensation paid to me. My livelihood is now uncertain as replanting the cocoa is very difficult considering my age and the strenuous effort involved. I'm powerless to challenge the chief or the contractor as I do not even own the land..." (Interview-2, Kakum).

“...On-farm tree planting constitutes an additional investment on the land aside from whatever use was initially agreed (say cocoa or oil palm). As such, any tree planted is subject to re-negotiation and the benefits thereof should be shared 50-50 between the farmer and the original landowners. Without this arrangement, the farmer has no right whatsoever to plant such trees irrespective of whether he or she holds the land under customary freehold..." (Interview-1, Ankasa). 
The above statements highlight the underlying complexity of on-farm tree planting investments which generally operate to dis-incentivise most households, particularly in the Kakum region. These observations were reiterated in other interviews and is consistent with previous observations in the literature that the existing tree tenure complexities act as a disincentive to farmers in undertaking tree planting investments (Owubah et al. 2001; Boni, 2005; Hansen et al. 2009; Damnyag et al. 2012; Hirons et al. 2018). It can therefore be concluded that other contextual factors operate to influence farmers' defacto conditions of tenure and the respective linkages to SLM investment decisions.

The duration (years) of plot use variable exerts a significant positive influence across all SLM investments, except in the case of the tree preservation model (Table 3). As was expected a priori, households are more likely to undertake soil improvement and long-term tree planting investments in plots they managed for a considerable time as they are deemed to be relatively more secure. This result appears to give the indication that high defacto tenure security under local tenurial arrangements, in some instances, is sufficient to incentivise farmers' adoption of both short and long-term SLM practices regardless of whether plots have formal legal titles.

Moreover, the preferential rights variable exerts a positive effect across all SLM investments but is only statistically significant in the case of on-farm tree planting. This suggests that farmers are more inclined to invest in tree planting on plots they exercised preferential rights, which is consistent with a priori expectations and literature (see Owubah et al. 2001; Zhang and Owiredu, 2007; Dzanku, 2008; Twerefou et al. 2011; Kabubo-Mariara and Linderhof, 2015). It highlights the importance farmers attributed to the right to bequeath or gift land (in a property rights sense) in their investment decision-making. During the field interviews, some farmers alluded to their ability to transfer farm 'property' to their children and/or spouses upon their demise as a strong motivating factor in 
undertaking long-term investments like tree planting. A 70-year old farmer from Amokwaosuazo (Ankasa) gave a typical explanation as follows:

“...In my view, what remains important in undertaking any investment on the land is the fact that my children will retain my farm in the event of my death. Considering my age now [70 years], I know I will not live long to enjoy the returns from my tree planting, but I undertook it all the same with the assurance that my children will inherit it and enjoy the benefits thereof one day...." (Interview-2, Ankasa).

What appears to be important is farmers' views regarding rather specific dimensions of land rights. In general, the extent that farmers were assured of their rights to bequeath land to their children and/ or spouses in practice, is correlated with investments in long-term tree planting irrespective of their (dejure) tenure status. Yet, this dimension of defacto/perceived tenure security is not adequately captured in theoretical models on the security-investment nexus. This further buttresses the argument that context-specific proxies (beyond formal individualised titling) are needed to adequately capture conditions of tenure security as they play out on the ground. The above interpretation also finds expression in Besley's (1995) argument that a farmer may not have the formal (dejure) right to bequeath, but this does not necessarily imply that they cannot bequeath (defacto) his land in practice. This further emphasises how narrow framings of tenure security as title documentation (legal security) do not sufficiently capture what constitutes tenure security, especially in Ghana's pluralistic context.

\section{(c) Perceived Security and SLM Adoption}

The overall results indicate that the influence of perceived security related variables on adoption of SLM investments is positive. All the perceived tenure security variables (socio-political status, previous land disputes and land use restrictions) significantly influence households' investment decision-making across all the three SLM investments. The socio-political status variable exerts a 
positive effect on all SLM practices suggesting that households with members occupying high positions within the local socio-political hierarchy ('elite' households) tended to invest more in long-term tree planting and retention practices compared to their 'non-elite' counterparts with no such positions (Table 3). Such 'elite' households tend to have relatively better access to multiple and more secure plots with favourable tenure arrangements affording them flexibility in their undertaking land management decision-making compared to households with no such affiliations. This inference derives from the observation that the existing socio-political relations and networking largely define land access arrangements in the two study areas. Alternatively, to the extent that the socio-political status of households is linked to strong intra and inter-community connections may imply relatively better access to new information and technologies thereby improving technical knowledge and capacity to invest in SLM practices. This finding is consistent with a priori expectation and supports Goldstein and Udry (2008) and Persha et al.'s (2015) findings that individuals who had powerful positions in the local political hierarchy and/ or close association with traditional authorities have more secure tenure rights (strong defacto tenure security over cultivated plots) and therefore tended to invest more in land conservation practices in southeast Ghana and Zambia respectively.

Paradoxically, previous land dispute is positively related to households' adoption of all three SLM practices (inorganic fertiliser application, on-farm tree planting and preservation of naturallyoccurring trees) contrary to the a priori expectation that the existence of prior land disputes is more likely to dissuade households from investment in long-term land improvements. Considering onfarm tree planting, it presupposes that households may undertake security-enhancing tree planting as a security-enhancing investment in plots subject to prior disputation. This finding is contradictory to the conventional view that prior land disputes leading to insecurity acts as a disincentive for investment in long-term SLM investments such as tree planting (Kabubo-Mariara, 2007; Dzanku, 2008; Twerefou et al. 2011; Damnyag et al. 2011; Persha et al. 2015; Ayamga et al. 2016). A 
plausible explanation for this contradiction could be that households whose plots were insecure (due to prior disputation) tended to invest more in tree planting as means of enhancing their future land rights (defacto tenure security) over such plots. This inference also finds expression in the argument that tenure insecurity could in some instances, also serve as an incentive for households to undertake security-enhancing investments (such as tree planting) given that such investments will in themselves increase security to the extent that eviction is no longer feasible (Besley, 1995; Brasselle et al. 2002; Otsuka et al. 2003; Sjaastad and Bromley, 1997). An alternative explanation could also be that purposeful on-farm tree planting provided somewhat clearer boundary demarcations in which case the incidence of future disputes over land is reduced. This is supported by the finding that an overwhelming majority of households in Kakum (94\% of plots) and Ankasa (82\% of plots) had planted trees or shrubs as the main plot boundary indicators in the studied communities. A typical view by a female farmer in Nkwantanang village (Kakum) is illustrative:

“...We plant some forest trees species (e.g. Ntome ${ }^{10}$ ) to delineate farmland boundaries so as to prevent any encroachment by adjoining neighbours...." (FGD-2, FGD-Nkwantanang, Kakum).

Likewise, land use restrictions also exert a positive influence on the adoption of soil improvement practices, only significant in the inorganic fertiliser application model (Table 3). This result seems to give the indication that even short-term investments are tenure enhancing for the extremely insecure (particularly caretaker farmers with precarious tenure) considering that their continuous use of land is predicated on the practice of good land husbandry.

In summary, it can be concluded that both secure and insecure tenure status can incentivize households' investment in SLM practices albeit through different mechanisms. This challenges earlier assertions that customary tenure arrangements impeded secondary right holders' control of production decisions (Government of Ghana, 1999; Damnyag et al. 2012; Antwi-Adjei et al. 2015).

\footnotetext{
10 Locally known as Ntome, Dracaena Manni is a shrub or tree often planted to demarcate farmland boundaries in cocoa growing regions of Ghana.
} 
It therefore follows that other non-tenurial factors operate to influence the perceived (and defacto) tenure status of households and ultimately their investment propensity. The ensuing discussion turns attention to the impact of non-tenurial factors on households SLM investment decision-making.

\subsection{Effects of Extra-Tenurial Factors on Adoption of SLM Investments}

Aside from the security-related factors, several non-tenurial factors including ethnicity, gender, age, education and access to extension support significantly influence households' investment propensity regarding uptake of SLM practices (Table 3). The ensuing discussion thus focuses on the effects of household demographic (ethnicity, age, gender and education), plot (plot size, number

of plots and distance from homestead), market (credit access, cooperative membership and extension support) and location characteristics as they are widely identified in the literature as important drivers of households' investment dynamics (Kabubo-Mariara, 2006, 2007; Abdulai et al. 2011; Persha et al. 2015; Nyanga et al. 2016).

\subsubsection{Household Socio-Demographic Characteristics and SLM Adoption}

The overall results in Table 3 show that the effect of household socio-demographic characteristics on adoption of the three SLM practices (fertiliser application, on-farm tree planting and conservation of naturally-occurring trees) is mixed. Interestingly, the community membership variable exerts a significant positive effect on preservation of naturally-occurring trees suggesting that migrant households are more likely to maintain naturally-occurring tree species in their plots relative to their indigenous counterparts. This result contradicts the commonly posited view that migrant farmers usually have a short-term planning horizon and therefore tended to invest less in long-term land improvements (like tree preservation) owing to their often-insecure tenure status within the customary tenure system (Abdulai and Goetz, 2011; Codjoe and Bilsborrow, 2012; Zhang and Owiredu, 2007; Afikorah-Danquah, 1997). It also puts to question Insaidoo et al.'s (2014) generalisation that investments in on-farm tree planting or conservation in Ghana favour 
natives with ownership rights more than migrants with less secure property rights. Further disaggregated analysis showed that all of the migrant settler farmers $(n=330)$ were internal migrants (mostly from the Central (35\%), northern (25\%) and Volta (20\%) regions respectively) who had migrated to the study areas in search of job opportunities within the cocoa sector, consistent with the literature on the history of Ghana's cocoa development (see Amanor, 2010; Hill, 1963). During the community FGDs, participants expressed that that the decision to maintain certain naturallyoccurring tree species was mainly based on their knowledge of the usefulness to cultivated crops and livelihoods generally. For instance, common naturally-occurring tree species such as Ceiba pentandra, Milicia excelsa, Cola nitida, Terminalia ivorensis, Altsonia boonei and Raufvolfia vomitoria were selectively maintained by farmers because of their shade (in case of cocoa farming), prevention of soil erosion, food, building and construction, medicinal and fuelwood attributes. Thus, to the extent that the foregoing attributes are important to households implies that they would necessarily preserve some natural regeneration trees species irrespective of their tenure status (cf. Otsuka and Runge, 2014; Otsuka and Place, 2014).

Whereas farmers' decision to invest in SLM practices is independent of gender, the age of the household decision-maker was found to have a significant negative relationship with SLM adoption (table 3). Older farmers are less likely to adopt SLM practices relative to younger ones which is contradictory to the common-placed view that the former tended to invest more in land because of their long experience and more accumulation of capital over time relative to their younger colleagues (Persha et al. 2015; Dzanku, 2008; Zhang and Owiredu, 2007). For instance, an additional year in the age of household decision-maker lowers the odds of investment in on-farm tree preservation by $2.6 \%$. To the extent that on-farm tree planting has a long payback period may operate to dissuade older farmers from undertaking such investments given their short-term planning horizon (and/ or risk averseness) vis-à-vis the complexities associated with current benefitsharing arrangements in the study areas and Ghana generally. 
At the same time, it is inferable from the results that farmers with secondary education are also less likely to invest in SLM practices relative to those with no formal education contrary to a priori expectation. This finding contradicts observations in the literature that households with high human capital tended to invest more in land improvements as they may have relatively better access to relevant information, technologies and other off-farm opportunities which increases their investment propensity (Owubah et al. 2001; Kabubo-Mariara, 2006; Abdulai et al. 2011; Kassie et al. 2013; Fentie et al. 2013). During the qualitative interviews, some respondents observed that 'highly educated' farmers mostly engaged in other off-farm economic activities (as teachers, forestry guards, extension agents etc.) which yielded additional income, thereby minimizing their overall dependence on their farming work relative to those with no education who are totally reliant on their farming work.

\subsubsection{Plot Characteristics and SLM Adoption}

As expected, the results in Table 3 demonstrate that short-term land improvements and long-term preservation of natural regeneration trees are more likely to be undertaken in larger farms relative to smaller ones. Taking short-term productivity-enhancing soil improvements, for instance, an additional acre of farmland (plot size) increases the odds of investing in fertiliser application by 5.7\%. This challenges notions that agriculture may intensify under increasing land pressure in SSA (e.g. Otsuka and Place, 2014).

Concerning the preservation of naturally-occurring trees, the overall results seem to suggest that farmers with fewer and smaller plots perceive more strongly that conserving trees trades off with crop productivity (table 3). Whereas this finding is consistent with Owubah et al. (2001) and Abdulai et al. (2011), it contradict those of Zhang and Owiredu (2007) and Dzanku (2008) who observed an inverse relationship between plot size and plantation investments in Ghana. To the extent that farmers with fewer and smaller plots find it more difficult to diversify their land use 
because of size constraints, it implies that those larger plots may be better positioned to engage more in land-intensive on-farm tree conservation investments. Two typical views by a female sharecropper and an agricultural extension officer in Kakum are illuminating:

“...To me, having higher shade tree density on my small farm is not beneficial as this can negatively affect the productivity of my cocoa trees as well as take up the space of other food crops we have planted...." (FGD-3, FGD-Totoda, Kakum).

“...There is currently widespread land fragmentation (due to growing land scarcity and inheritance) so farmers have reduced farm sizes and not particularly keen on conserving trees despite having the knowledge that trees provide shade and have ecological importance... (Interview-5, Kakum)

Surprisingly, the coefficient of the distance to plot from homestead variable is positive across all three SLM investments but only statistically significant in the case of inorganic fertiliser application. This result contradicts both theory and the a priori expectation that farmers with plots farther from their place of residence are more likely to invest less (relative to nearby plots) considering that opportunity cost of transportation of labour and farm inputs increases (Gebremedhin and Swinton, 2003; Fentie et al. 2013). It was also gathered from informal discussions with key informants that those farmers who lived further away either appointed caretakers or personally paid equal attention to both their distant and nearby farms to safeguard against possible threats to their defacto tenure security through encroachment and/ or expropriation. This latter interpretation is further supported by the fact that poor land husbandry and land abandonment are perceived as valid grounds for the loss of land rights in the studied communities. This further highlights the interaction between extra-tenurial considerations and defacto conditions of tenure which operate in tandem to influence the ultimate household SLM investment decisions in the study regions. 


\subsubsection{Market Factors and SLM Adoption}

The overall results indicate that the effect of the access to credit variable on adoption of SLM practices is mixed. However, the access to credit variable exerts a significant negative effect on adoption of long-term SLM practices (tree planting and preservation of naturally-occurring trees). Contrary to a priori expectation, this latter result suggests that households with access to credit opportunities are less likely to engage in long-term SLM practices in their plots. This finding is surprising to the extent that that access to credit opportunities by farmers is commonly believed as plausible avenue to stimulate their investment propensity (Kassie et al. 2015). The limited availability of credit opportunities in the study areas and rural Ghana generally as previously indicated could probably explain the above contradiction (Abdulai and Domeher, 2012). Besides, the fact that majority of the households surveyed (83\%) self-financed their farming activities vis-àvis the cost-intensive nature and attendant uncertainties of tree planting perhaps dissuaded most households from investing altogether. Furthermore, it was gathered from the informal interviews that households tended to use such credit facilities, if available, to settle their immediate livelihood and other social imperatives (like health, education, funeral and marriage ceremonies etc.) before considering investments in long-term non-productivity related SLM practices - on-farm tree planting and conservation of naturally-occurring tree species - which are perceived as secondary concerns.

\subsubsection{Locational Characteristics and SLM Adoption}

The location dummy variable which was included in the models (Table 2) to capture study area specific effects on SLM investments seem to indicate regional differences regarding adoption of SLM practices (except on-farm tree planting), with households in Kakum, for example, more likely to invest in soil improvement relative to households in Ankasa. To the extent that older farms required more investments in soil improvements in order to replenish fertility (for increased 
productivity) might explain the locational differences between Kakum and Ankasa considering the average farm age of 15.4 and 13.0 years respectively. Besides, the severity of the land shortage problem vis-à-vis the fact that sampled farm sizes were on average smaller in Kakum (8.66 acres) relative to Ankasa (11.99 acres) could also explain the regional difference regarding the adoption of on-farm tree planting as an SLM strategy. Altogether the foregoing further underscores the importance of context-specific approaches to avoid the risk of masking key location-based differences in households' land use investment dynamics through extrapolating from empirical data. Although there are increasingly calls for multi-country studies, is evident that within countries important differences exist with respect the land management which are critical to understand to avoid replicating overly generic policy response.

\section{Conclusion and Policy Implications}

This paper investigates the linkages between land tenure arrangements and households' investment decision-making regarding the uptake of SLM practices at the farm plot-level. This is against the backdrop of the neoclassical economic theory postulation that well defined and secure land rights (tenure security) leads to enhanced investment incentives. The findings suggest that tenure security is indeed important for adoption of SLM practices, particularly long-term tree planting. However, the different dimensions of tenure have a mixed relationship with SLM investments meaning that there is no empirical basis that supports generalised theories of the relationship between tenuresecurity and SLM investments. The econometric analysis also demonstrates that, in addition to legal (documented and individualised) forms of tenure security, other (defacto and/ or perceived) security-related factors (including duration of plot use, socio-political status and land disputes) play an influential role in farmers' investment propensity regarding SLM adoption. For instance, the duration of plot use (defacto security) and socio-political status of households combine to improve 
(perceived) tenure security and ultimately investment decision-making even without formal legal titles. These findings point to important policy implications.

While not necessarily downplaying the relevance of formal land titling in bolstering the (dejure) tenure security of farmers, the analysis raises fundamental questions as to the narrow definition of tenure security as formal individualised land titling without taking due cognizance of other contextual factors within the local socio-political system that operate to positively influence security (Van Gelder, 2010; Broegaard, 2013; Simbizi et al. 2014). It therefore follows that without consideration of such contextual security-related factors, users of non-registered farmlands, for example, could be wrongly labelled as 'insecure' leading to inefficient or ineffective policy prescriptions on formalisation and perhaps causing further uncertainties or exacerbating inequalities (Ayamga et al. 2015). This may well explain why decades of implementation of land titling programmes in SSA have failed to realize the desired objective of improving tenure security (ibid; Bromley, 2009).

Importantly, the paper highlights that the land tenure security and investment nexus is not straightforward nor generalizable, but complex and embedded within the broader geographical, institutional and social-cultural context. Despite the importance of non-tenurial factors (including socio-demographic factors, access to credit opportunities and targeted extension support services) in influencing household investment decisions, they remain at the fringes of the current policy discourse on sustainable land management in Ghana. Building on Bugri (2008) and Lawry et al.'s (2017) analysis it can be concluded that tenure security alone is not a sufficient condition for achieving sustainable land management in Ghana and SSA generally. As this paper further demonstrates, the degree of importance farmers attached to informal written documentation (proxy for legal security) in safeguarding their tenure rights, on the one hand, has a significant positive effect on their adoption of long-term on-farm tree planting. Conversely, the possession of informal 
documentation (evidencing ownership/ use of landholdings) showed a significant negative association with households' investment in short-term productivity-enhancing land improvement practices (sub-Section 4.2.1).

The markedly different effects of informal documentation on households' adoption of SLM practices seems to underline the extent to which the legal dimension of tenure security shapes households' investment decision-making which might not necessarily lead to enhanced investment incentives. This finding echoes the argument in the growing literature that warns against the risk of over-romanticizing statutory legal systems given the interplay of contextual factors that influe nce tenure security and associated investment dynamics (Asaaga and Hirons, forthcoming; Lawry et al. 2017; Broegaard, 2013; Bromley, 2009). As Broegaard (2013) argues, formal land titling only create tenure security in combination with other important contextual factors. Thus, while improving dejure tenure rights may contribute towards bolstering the perceived (and/ or defacto) security of landholders, solely focusing on the legal dimension of tenure security risks overlooking other important contextual factors that might contribute to insecurity (from a defacto security perspective), ultimately reducing the investment propensity of farmers. The existence of other contextual factors such as previous land dispute, imposition of land use restrictions and the sociopolitical status of individual household members within the local socio-political system interact to influence the perceived (social) legitimacy and defacto situation of the tenure rights of respective farm-households. More nuanced and flexible analytical approaches that accommodate the complexity and diversity of local tenurial arrangements remain necessary to better understand, on the one hand, what constitutes tenure security within a socio-political context and, on the other hand, how the different dimensions of tenure security interact to differentially shape farm-household investment decision-making.

Likewise, policymakers in their design and implementation of development interventions should focus attention on non-tenurial factors like targeted extension support services (that will enhance 
market performance) whilst simultaneously addressing problems of tenure insecurity (from the tripartite tenure security perspective) to engender the appropriate incentives to promote widespread adoption of SLM practices in rural Ghana. Moreover, to the extent that there may be trade-offs between incentivising SLM and supporting the claims of poorer and more vulnerable groups on land, it is important that adequate provisions are also made for alleviating such inequality concerns. As evidenced in the foregoing, credit provision for instance does not seem to correlate with SLM investment (Table 3) casting some doubt on the impact of efforts to extend credit for agriculture are, while extension support for on-farm tree planting seems important (see sub-Section 4.3.3). To the extent that one component of the current climate-smart cocoa initiative is to increase shade trees on farms, then policymakers should consider prioritising extension over credit in engendering the requisite incentives to stimulate widespread on-farm tree planting in the study regions.

Without the institution of such broad-based and inclusive measures to tackle the barriers to extension support services and other market imperfections (including the availability, technical and economic viability of respective SLM technologies) then the current policy focus on enhancing legal tenure security (through systematic rural titling initiatives) towards achieving the theoretical benefits of livelihood security and investment in SLM may be insufficient. In any event, tackling issues of (legal) tenure insecurity may be desirable for other reasons, or may be effective, but due to interactions with other contextual factors, it is likely that they will deliver a range of outcomes (both positive and negative) pertaining to land conservation investments. This indicates a requirement to think more deeply about priorities with respect to SLM interventions, particularly in emerging contexts like Ghana and SSA generally. 


\section{References}

[1] Abdulai, A., Owusu, V. and Goetz, R. (2011). Land tenure differences and investment in land improvement measures: Theoretical and empirical analyses. Journal of Development Economics 96, 66-78.

[2] Abdulai, A. and Goetz, R. (2014). Time-related characteristics of tenancy contracts and investment in soil conservation practices. Environmental and Resource Economics, 59(1), pp.87-109.

[3] Afikorah-Danquah, S. (1997). Local Resource Management in the Forest-Savanna Transition Zone: The Case of Wenchi District, Ghana. IDS Bulletin, 28(4), pp.36-46.

[4] Ali, D.A., Deininger, K. and Goldstein, M. (2014). Environmental and gender impacts of land tenure regularization in Africa: pilot evidence from Rwanda. Journal of Development Economics, 110, pp.262-275.

[5] Amanor, S.K., with Diderutuah M.K. (2001). Share Contracts in the Oil Palm and Citrus Belt of Ghana: Land Tenure and Resource Access in West Africa.

[6] Amanor, K.S. (2010). Family values, land sales and agricultural commodification in SouthEastern Ghana. Africa, 80(1), pp.104-125.

[7] Antwi-Agyei, P., Dougill, A. J., \& Stringer, L. C. (2015). Impacts of land tenure arrangeme nts on the adaptive capacity of marginalized groups: The case of Ghana's Ejura Sekyedumase and Bongo districts. Land Use Policy, 49, 203-212.

[8] Arnot, C. D., Luckert, M. K. and Boxall, P. C. (2011). What is tenure security? Conceptual Implications for Empirical Analysis. Land Economics, 87(2), 297-311.

[9] Asaaga, F.A. and Hirons, M.A. (2019). Windows of opportunity or windows of exclusion? Changing dynamics of tenurial relations in rural Ghana. Land Use Policy, 87, p.104042. 
[10] Asaaga, F.A. and Hirons, M.A. (forthcoming). Understanding the Dynamics of Land Tenure Security in Customary Dominated Contexts: Implications for Incremental Formalisation of Rural Land Rights in Ghana.

[11] Asare, R.A. (2013). Climate-Smart cocoa in Ghana: Achievements and the way forward. Forest Trends and Nature Conservation Research Centre. Available at https://www.forest$\underline{\text { trends.org/wp-content/uploads/imported/FT_cacao_Ghana_Apr29013.pdf }}$ (Accessed: $15 / 08 / 2019)$

[12] Ayamga, M. and Dzanku, F. (2013). The Land Rights and Farm Investment Ghana: The Missing Link in the Operationalisation of Tenure Security. In 2013 AAAE Fourth International Conference, September 22-25, 2013, Hammamet, Tunisia (No. 161478). African Association of Agricultural Economists (AAAE).

[13] Ayamga, M., Yeboah, R.W.N. and Ayambila, S.N. (2016). An analysis of household farm investment decisions under varying land tenure arrangements in Ghana. Journal of Agriculture and Rural Development in the Tropics and Subtropics (JARTS), 117(1), pp.21-34.

[14] Berry, S. (2009). Building for the future? Investment, land reform and the contingencies of ownership in contemporary Ghana. World Development, 37 (8), pp. 1370-1378.

[15] Besley, T. (1995). Property Rights and Investment Incentives: Theory and Evidence from Ghana. Journal of Political Economy, Vol. 103, No.5, 903- 937. Available at www.jstor.org/stable/2138750 (Accessed on 11/01/2014).

[16] Blackman, A., Corral, L., Lima, E.S. and Asner, G.P. (2017). Titling indigenous communities protects forests in the Peruvian Amazon. Proceedings of the National Academy of Sciences, 114(16), pp.4123-4128.

[17] Blay, D. and Damnyag, L. (2008). Land Tenure Systems and Land Degradation in Ghana. Institute of Statistical, Social \& Economic Research, University of Ghana. 
[18] Boni, S. (2005). Clearing the Ghanaian forest: Theories and practices of acquisition, transfer and utilisation of farming titles in the Sefwi-Akanarea (pp. 1-272). Institute of African Studies.

[19] Boni, S. (2006). Ghanaian farmers' lukewarm reforestation: Environmental degradation, the timber option and ambiguous legislation. In Colloque international "Les frontières de la question foncière-At the frontier of land issues (pp. 1-12).

[20] Boone, C. and Duku, D.K. (2012). Ethnic land rights in western Ghana: landlord-stranger relations in the democratic era. Development and Change, 43(3), pp.671-693.

[21] Boserup, E. (1965). The condition of agricultural growth. The Economics of Agrarian Change under Population Pressure.

[22] Brasselle, A. S., Gaspart, F., \& Platteau, J. P. (2002). Land tenure security and investment incentives: puzzling evidence from Burkina Faso. Journal of Development Economics, 67(2), 373-418.

[23] Broegaard, R.B. (2013). Biting the barefoot: land titles and tenure security in the context of inequality. Report, Danish Institute for International Studies, (32).

[24] Bugri, J.T. (2008). The Dynamics of Tenure Security, Agricultural Production and Environmental Degradation in Africa: Evidence from Stakeholders in Northeast Ghana. Land Use Policy, 25, 271-285.

[25] Codjoe, S.N.A. and Bilsborrow, R.E. (2012). Are migrants exceptional resource degraders? A study of agricultural households in Ghana. GeoJournal, 77(5), pp.681-694.

[26] Cordingley, J.E., Snyder, K.A., Rosendahl, J., Kizito, F. and Bossio, D. (2015). Thinking outside the plot: addressing low adoption of sustainable land management in sub-Saharan Africa. Current Opinion in Environmental Sustainability, 15, pp.35-40.

[27] Damnyag, L., Saastamoinen, O., Appiah, M., Pappinen, A. (2012). Role of tenure insecur ity in deforestation in Ghana's high forest zone. Forest Policy Economics 14, 90-98. (Accessed on $21 / 01 / 2014)$. 
[28] Damnyag, L., Saastamoinen, O., Blay, D., Dwomoh, F.K., Anglaaere, L.C.N, Pappinen, A. (2013). Sustaining protected areas: Identifying and controlling deforestation and forest degradation drivers in the Ankasa Conservation Area, Ghana.

[29] Deininger, K. (2003). Land Policies for Growth and Poverty Reduction. Word Bank and Oxford University Press.

[30] Deininger, K. and Jin, S. (2006). Tenure security and land-related investment: Evidence from Ethiopia. European Economic Review, 50(5), 1245-1277.

[31] De Soto, H. (2003). The mystery of capital: Why capitalism triumphs in the West and fails everywhere else. Basic Civitas Books.

[32] Duncan, B.A. \& Brants, C. (2004). Access to and Control Over Land from a Gender Perspective: A Study Conducted in the Volta Region. Commissioned by the SNV Netherlands Development Organisation - Ghana Office and the Gender and Development Unit of the Food and Agriculture Organisation of the UN Regional Office for Africa (FAORAF). Accra, Ghana: SNV/FAO.

[33] Dzanku, F.M. (2008). Land Rights, Sustainable Natural Resource Use and Agricultural Productivity in Ghana. Institute of Statistical, Social \& Economic Research, University of Ghana.

[34] Food and Agriculture Organization (FAO) (2011). State of the World's Forests 2011. (FAO, Rome).

[35] Fentie, D., Fufa, B. and Bekele, W. (2013). Determinants of the use of soil conservation technologies by smallholder farmers: The case of Hulet Eju Enesie District, East Gojjam Zone, Ethiopia. Asian Journal of Agriculture and Food Sciences (ISSN: 2321-1571), 1(04).

[36] Fenske, J. (2011). Land tenure and investment incentives: Evidence from West Africa. Journal of Development Economics, 95(2), pp.137-156. 
[37] Field, A., 2000. Discovering statistics using SPSS for Windows: Advanced techniques for the beginner. Introducing statistical methods Show all parts in this series. Available online at http://www.cee.uma.pt/ron/Discovering\%20Statistics\%20Using\%20SPSS,\%20Second\%20E dition\%20CD-ROM/Chapter\%2002/Field2000(Chapter1).pdf (Accessed on 20/06/2016).

[38] Fuentes. P.A., Bumbu, B. and Johnson, M. (2012). Improving fertiliser markets in West Africa: the fertiliser supply chain in Ghana. IFPRI. Available online at https://africafertilizer.org/wpcontent/uploads/2017/04/The-Fertilizer-Supply-Chain-in-Ghana.pdf $\quad$ Accessed on $12 / 10 / 2018)$.

[39] COCOBOD (Ghana Cocoa Board) (2012). Cocoa Report Annual. Available online at https://apps. fas.usda.gov/newgainapi/api/report/downloadreportbyfilename?filename=Cocoa \%20Report\%20Annual_Accra_Ghana_3-15-2012.pdf (Accessed on 17/12/2019).

[40] GSS (Ghana Statistical Service) (2014). Ghana Living Standards Survey 6. Available online at http://www.statsghana.gov.gh/docfiles/glss6/GLSS6_Main\%20Report.pdf (Accessed on 05/03/2015).

[41] Gockowski, J., Robiglio, V., Muilerman, S. and Agyeman, N. F. (2011). Agricultural intensification as a strategy for climate mitigation in Ghana. Available online at https://cgspace.cgiar.org/rest/bitstreams/15262/retrieve (Accessed on 18/05/17).

[42] Goldstein, M., \& Udry, C. (2008). The profits of power: Land rights and agricultural investment in Ghana. Journal of political Economy, 116(6), 981-1022.

[43] GoG (Government of Ghana) (1999). National Land Policy. Accra, Ghana.

[44] Government of Ghana (2010). REDD+ Readiness Preparation Proposal Ghana. Submission to the Forest Carbon Partnership Facility. Available online at http://www.forestcarbonpartnership.org/sites/forestcarbonpartnership.org/files/Documents/P DF/Jan2011/Revised_Ghana_R-PP_2_Dec-2010.pdf (Accessed on 06/03/2015). 
[45] GoG (2014). Ghana Shared Growth and Development Agenda (GSDA) II, 2014-2017. National Development Planning Commission, Accra, Ghana.

[46] Gyasi, E.A. (1994). The adaptability of African communal land tenure to economic opportunity: the example of land acquisition for oil palm farming in Ghana. Africa, 64(3), pp.391-405.

[47] Hansen, C. P., Lund, J. F., \& Treue, T. (2009). Neither Fast, Nor Easy: He Prospect of Reduced Emissions from Deforestation and Degradation (REDD) in Ghana. International Forestry Review, 11(4), 439-455.

[48] Hausermann, H., Ferring, D., Atosona, B., Mentz, G., Amankwah, R., Chang, A., Hartfie ld, K., Effah, E., Asuamah, G.Y., Mansell, C. and Sastri, N. (2018). Land-grabbing, land-use transformation and social differentiation: Deconstructing "small-scale" in Ghana's recent gold rush. World Development, 108, pp.103-114.

[49] Hill, P. (1963). The Migrant Cocoa-Farmers of Southern Ghana: A Study in Rural Capitalism. ed. M. Last, Classics in African Anthropology. Oxford: James Curry Publishers

[50] Hirons, M., McDermott, C., Asare, R., Morel, A., Robinson, E., Mason, J., Boyd, E., Malhi, Y. and Norris, K. (2018). Illegality and inequity in Ghana's cocoa-forest landscape: How formalization can undermine farmers control and benefits from trees on their farms. Land use policy, 76, pp.405-413.

[51] Insaidoo, T.F., Ros-Tonen, M.A. and Acheampong, E. (2013). On-farm tree planting in Ghana's high forest zone: The need to consider carbon payments. In Governing the provision of ecosystem services (pp. 437-463). Springer Netherlands.

[52] Insaidoo, T.F.G., Derkyi, M. and Acheampong, E. (2014). Farm Level Tree Planting in Ghana: Potential for Reducing Vulnerability and Mitigating Climate Change. JENRM, 1(1), pp.19-28. 
[53] IUCN (International Union for Conservation of Nature) (2010). Parks and Reserves in Ghana: Management Effectiveness Assessment of Protected Areas. Ouagadougou, BF: UICN/PACO. Available online at https:/portals.iucn.org/library/sites/library/files/documents/2010-073.pdf (Accessed on 17/12/2019).

[54] Jacoby, H.G. and Minten, B. (2007). Is land titling in Sub-Saharan Africa cost-effective? Evidence from Madagascar. The World Bank Economic Review, 21(3), pp.461-485.

[55] Joireman, S.F. (2006). Applying property rights theory to Africa: the consequences of formalizing informal land rights. In meeting of the International Society for New Institutional Economics, Boulder.

[56] Kabubo-Mariara, J. (2006). Land conservation in Kenya: The role of property rights (No. RP_153). African Economic Research Consortium.

[57] Kabubo-Mariara, J. (2007). Land conservation and tenure security in Kenya: Boserup's hypothesis revisited. Ecological economics, 64(1), pp.25-35.

[58] Kabubo-Mariara, J. and Linderhof, V. (2015). Tenure Security, Sustainable Land Management and Poverty: Case Studies from Kenya. Technical Report. Available online at https://www.researchgate.net/publication/240633976 (Accessed on 20/06/2016).

[59] Kasanga, K. (1996). Land tenure, resource access and decentralisation: The political economy of land tenure in Ghana, in Managing Land Tenure and Resource Access in West Africa. Proceedings of a Regional Workshop, Gorée, Senegal.

[60] Kasanga, K. and Kotey, N. A. (2001). "Land management in Ghana: building on tradition and Modernity" International Institute for Environment and Development. London.

[61] Kasanga, K. (2002). World Bank Land Policy for Pro-Poor Development Policy Research Report: A Review. Accra, Ghana. 
[62] Kassie, M., Jaleta, M., Shiferaw, B., Mmbando, F. and Mekuria, M. (2013). Adoption of interrelated sustainable agricultural practices in smallholder systems: Evidence from rural Tanzania. Technological forecasting and social change, 80(3), pp.525-540.

[63] Kassie, M., Teklewold, H., Jaleta, M., Marenya, P. and Erenstein, O. (2015). Understanding the adoption of a portfolio of sustainable intensification practices in eastern and southern Africa. Land Use Policy, 42, pp.400-411.

[64] Kirui, K. O. (2016). Drivers of Sustainable Land Management in Eastern Africa. A paper prepared for presentation at the "2016 World Bank Conference on Land and Poverty" The World Bank - Washington DC, March 14-18, 2016.

[65] Kolavalli, S. and Vigneri, M. (2011). Cocoa in Ghana: Shaping the success of an economy. Yes, Africa can: success stories from a dynamic continent, pp.201-218.

[66] La Anyane, S. (1962) Agriculture in the General Economy: Factors Affecting Agricultural Production, in Wills, J. (ed.), Agriculture and Land Use in Ghana. Oxford University Press.

[67] Lambrecht, I.B. (2016). "As a husband I will love, lead, and provide." Gendered access to land in Ghana. World Development, 88, pp.188-200.

[68] Lawry, S., Samii, C., Hall, R., Leopold, A., Hornby, D. and Mtero, F. (2017). The impact of land property rights interventions on investment and agricultural productivity in developing countries: a systematic review. Journal of Development Effectiveness, 9(1), pp.61-81.

[69] Liniger, H.P., Mekdaschi Studer, R., Hauert, C. and M. Gurtner (2011). Sustainable Land Management in Practice - Guidelines and Best Practices for Sub-Saharan Africa. Terr Africa, World Overview of Conservation Approaches and Technologies (WOCAT) and Food and Agriculture Organization of the United Nations (FAO). Available online at http://www.fao.org/docrep/014/i1861e/i1861e.pdf (Accessed on 27/04/2017).

[70] Ma, X., Heerink, N., Feng, S. and Shi, X., (2015). Farmland tenure in China: Comparing legal, actual and perceived security. Land Use Policy, 42, pp.293-306. 
[71] Mbow, C., Van Noordwijk, M.,Luedeling, E., Neufeldt, H., Minang, P.A. and Kowero, G. (2014). Agroforestry solutions to address food security and climate change challenges in Africa. Current Opinion in Environmental Sustainability, 6: 61-67.

[72] Mirzabaev, A., Nkonya, E., Goedecke, J., Johnson, T. and Anderson, W. (2016). Global Drivers of Land Degradation and Improvement. In Economics of Land Degradation and Improvement-A Global Assessment for Sustainable Development (pp. 167-195). Springer International Publishing.

[73] Nigussie, Z., Tsunekawa, A., Haregeweyn, N., Adgo, E., Nohmi, M., Tsubo, M., Aklog, D., Meshesha, D.T. \& Abele, S. (2017). Factors influencing small-scale farmers' adoption of sustainable land management technologies in north-western Ethiopia. Land Use Policy, 67, pp.57-64.

[74] Nkonya, E., Pender, J., Benin, S., \& Kato, E. (2008). Land rental markets and land management: Evidence from Uganda. In S. Holden, K. Otsuka, \& F. Place (Eds.), Emerging land markets in Africa-implications for poverty, equity and efficiency. Washington, D.C.: Resources for the Future Press.

[75] Nkonya, E., Gerber, N., Baumgartner, P., Von Braun, J., De Pinto, A., Graw, V., Kato, E., Kloos, J. and Walter, T. (2011). The economics of desertification, land degradation, and drought toward an integrated global assessment. ZEF-Discussion Papers on Development Policy, (150).

[76] Nkonya, E., Johnson, T., Kwon, H. Y., and Kato, E. (2016). Economics of Land Degradation in Sub-Saharan Africa. In Economics of Land Degradation and Improvement-A Global Assessment for Sustainable Development (pp. 215-259). Springer International Publishing.

[77] Nyanga, A., Kessler, A. and Tenge, A. (2016). Key socio-economic factors influencing sustainable land management investments in the West Usambara Highlands, Tanzania. Land Use Policy, 51, pp.260-266. 
[78] Okoth-Ogendo, H.W.O. (1994). "Land Tenure, Agrarian Legislation and Environmental Management Systems" in R.J. Bakema (ed.) Land Tenure and Sustainable Land Use, Bulletin 332, Amsterdam: Royal Tropical Institute, pp. 21-30.

[79] Ostrom, E. (2010). Polycentric systems for coping with collective action and global environmental change. Global environmental change, 20(4), pp.550-557.

[80] Otsuka, K., Quisumbing, A.R., Payongayong, E. and Aidoo, J.B. (2003). Land tenure and the management of land and trees: the case of customary land tenure areas of Ghana. Environment and Development Economics, 8(01), pp.77-104.

[81] Otsuka, K. and Place, F. (2014). Changes in land tenure and agricultural intensification in subSaharan Africa. World Institute for Development Economics Research (WIDER) Working Paper, 51.

[82] Owubah, C.E., Le Master, D.C., Bowker, J.M. and Lee, J.G. (2001). Forest tenure systems and sustainable forest management: the case of Ghana. Forest Ecology and Management, 149(1), pp.253-264.

[83] Owusu, V., Gunning, J.W. and Burger, K. (2007). Do Tenure Differences Influence the Improvement of Quality of Rented Land? Empirical Evidence from Rural Ghana. In 106th Seminar, October 25-27, 2007, Montpellier, France (No. 7933). European Association of Agricultural Economists.

[84] Pender, J. and Gebremedhin, B. (2008). Determinants of agricultural and land management practices and impacts on crop production and household income in the highlands of Tigray, Ethiopia. Journal of African Economies, 17(3), pp.395-450.

[85] Persha, L., Stickler, M. M. and Huntington, H. (2015). Does Stronger Land Tenure Security Incentivise Smallholder Climate-Smart Agriculture? Understanding Drivers of Agricultural Investment in Zambia's Eastern Province. Annual World Bank Conference on Land and Poverty, Washington, DC. 
[86] Peprah, K., Yiran, G. B. and Owusu, A. B. (2014). Land Use Trajectories, Forest Cover Change and Consequential Land Degradation of the Asunafo Forest, Ghana'. International Journal of Innovative Research \& Studies, 3(1), 447-503.

[87] Peters, P.E. (2004). Inequality and social conflict over land in Africa. Journal of agrarian change, 4(3), pp.269-314.

[88] Pagiola, S. (1999). Economic Analysis of Rural Land Administration Projects. Washington, DC: World Bank.

[89] Place, F. and Hazell, P. (1993). Productivity effects of indigenous land tenure systems in sub-Saharan Africa. American journal of agricultural economics, pp.10-19.

[90] Place, F. and Migot-Adholla, S.E. (1998). The economic effects of land registration on smallholder farms in Kenya: evidence from Nyeri and Kakamega districts. Land Economics, pp.360-373.

[91] Place, F. and Otsuka, K. (2000). Population pressure, land tenure, and tree resource management in Uganda. Land economics, pp.233-251.

[92] Place, F. (2009), Land Tenure and Agricultural Productivity in Africa: A Comparative Analysis of the Economics Literature and Recent Policy Strategies and Reforms. World Development, Vol. 37(8), pp.13426-1336.

[93] Platteau, J.P. (1996). The evolutionary theory of land rights as applied to sub-Saharan Africa: a critical assessment. Development and change, 27(1), pp.29-86.

[94] Platteau, J.P. (2000). Institutions, Social Norms and Economic Development: Fundamentals of Development Economics. Amsterdam: Harwood Academic Publishers

[95] Quisumbing, A. R., Payongayong, E., Aidoo, J. B. and Otsuka, K. (2001). Women's Land Rights in the Transition to Individualized Ownership: Implications for Tree-Resource Management in Western Ghana*. Economic Development and Cultural Change, 50(1), 157182. 
[96] Robinson, B.E., Holland, M.B. and Naughton-Treves, L. (2014). Does secure land tenure save forests? A meta-analysis of the relationship between land tenure and tropical deforestation. Global Environmental Change, 29, pp.281-293.

[97] Ruf, F.O. (2011). The myth of complex cocoa agroforests: the case of Ghana. Human Ecology, 39(3), pp.373-388.

[98] Sewornu, R. E. (2010). The Role of good governance in improving women's access right to land. OIDA International Journal of Sustainable Development, 1(5), 37-53.

[99] Shiferaw, B. and Holden, S.T. (1998). Resource degradation and adoption of land conservation technologies in the Ethiopian highlands: a case study in Andit Tid, North Shewa. Agricultural economics, 18(3), pp.233-247.

[100] Simbizi, M.C.D., Bennett, R.M. and Zevenbergen, J. (2014). Land Tenure Security: Revisiting and Refining the Concept for sub-Saharan African Rural Poor. Land Use Policy, 36, pp. 231-238.

[101] Sjaastad, E. and Bromley, D. W. (1997). Indigenous land rights in Sub-Saharan Africa: Appropriation, security and investment demand. World Development, 25(4), 549-562.

[102] Sjaastad, E. and Bromley, D.W. (2000). The prejudices of property rights: On individualism, specificity, and security in property regimes. Development policy review, 18(4), pp.365-389.

[103] Twerefou, D. K., Osei-Assibey, E. and Agyire-Tettey, F. (2011). Land Tenure Security, Investments and the Environment in Ghana. Journal of Development and Agricultural Economics 3(6).

[104] Tran, H., Nguyen, Q. and Kervyn, M. (2018). Factors influencing people's knowledge, attitude, and practice in land use dynamics: A case study in Ca Mau province in the Mekong delta, Vietnam. Land Use Policy, 72, pp.227-238. 
[105] Unruh, J. D. (2008). Carbon sequestration in Africa: The land tenure problem. Global Environmental Change, 18(4), 700-707.

[106] Van Gelder, J.L. (2010). What is Tenure Security? The Case of a Tripartite View. Land Policy, 27, pp. 449-456.

[107] Van Gelder, J. L. and Luciano, E. C. (2015). Tenure security as a predictor of housing investment in low-income settlements: testing a tripartite model. Environment and Planning A, 47(2), 485-500.

[108] Whitehead, A. and Tsikata, D. (2003). Policy Discourses on Women's Land Rights in subSaharan Africa: The Implications of the re-turn to the Customary. Journal of Agrarian Change 3 (1 and 2): pp. 67-112.

[109] World Bank (2010). Development and climate change. World Development Report, 2010. Washington DC. $418 \mathrm{p}$.

[110] Yaro, J.A. and Hesselberg, J. (2010). Poverty and Land Degradation Linkages in the Developing World. Ghana Journal of Geography, 2(1), pp.25-46.

[111] Zhang, D. and Owiredu, E.A. (2007). Land tenure, market, and the establishment of forest plantations in Ghana. Forest Policy and Economics, 9(6), pp.602-610. 